\title{
Piety and Presence in the Postclassical Sultanic Mosque
}

\author{
Ünver Rüstem
}

When, in 989/1581, the Ottoman historian Gelibolulu Muṣtafā 'Ālì (d. 1008/ 16oo) wrote that only those sultans who had successfully waged holy war should build religious foundations, he was spelling out an attitude that must have been widely shared at the time, and that continues to inform modern perceptions of Ottoman architecture. ${ }^{1}$ The idea that even the sovereign should be bound by codes of decorum was well enough accepted that 'Ālìs dictum-a passage from his famous Counsel for sultans (Nüṣhatü's-selāțin) —-was intended for no less a reader than Murād III (r. 982-1003/1574-1595), who himself refrained from erecting a mosque in Istanbul because of his relatively humble military achievements. Underscoring the association between empire building and imperial building were the numerous mosques that Murād's more successful predecessors had added to the Ottoman capital since its conquest. This series of monuments culminated in 964/1557 with the completion of the mighty hilltop complex of Süleymān the Magnificent (r. 926-974/1520-1566), whose transformative intervention in the cityscape was to remain unrivaled until the early eleventh/seventeenth century, when the young Ahmed I (r. 10121026/16o3-1617) decided to flout convention and build a great mosque despite having no significant victories to his name. ${ }^{2}$

Ahmed's apparent disregard for the rules has helped to make his mosque a turning point in modern art-historical accounts, which have tended to view the building as an overblown vanity project that ushered in not only aesthetic decline, but also semiotic attenuation. After the tenth/sixteenth century, the story goes, the imperial mosque ceased to be a convincing emblem of the state's $g \bar{a} z \bar{\imath}$ (holy warrior) ideology, and scholars have often treated later examples of the genre as if they were conceived and viewed outside the codified

1 'Ālì, Counsel i, 54, 146, quoted and discussed in Necipoğlu, The age of Sinan 6o.

2 Necipoğlu, The age of Sinan 207-222, 256-257, 511; Rüstem, The spectacle. For an overview of the sultanic mosque and its symbolism, see Crane, Ottoman sultan's mosques. For an analysis of the "rule" described by Mușțafā 'Ālī and the strategies developed in response to it, see Budak, "The temple of the incredulous." 
religiopolitical framework that we take for granted in relation to earlier centuries. ${ }^{3}$ My aim here is to challenge this interpretation by demonstrating the ways in which notions of religious - and specifically Sunni-propriety and triumphalism remained key to the postclassical sultanic mosque, even as the empire's expansion slowed and eventually stopped. Far from overturning the standards that made such architecture meaningful, the later mosques renegotiated them in response to changing circumstances, engendering new visual, ceremonial, and discursive strategies by which to maintain the sultanate's image as the spearhead of Islamic orthodoxy. Above all, the reformulation of the imperial mosque was underpinned by, and itself contributed to, a new model of kingship that increasingly emphasized the ruler's auspicious presence in the capital as a benevolent steward over his subjects. This development, which spanned the eleventh/seventeenth and twelfth/eighteenth centuries, is exemplified by three monuments that will punctuate my discussion: the aforementioned Sultan Ahmed Mosque (1018-1026/16o9-1617), the Nuruosmaniye Mosque (11611169/1748-1755), and the Beylerbeyi Mosque (1191-1192/1777-1778). ${ }^{4}$ Each marking a pivotal juncture in the imperial mosque's adaptive evolution, these buildings testify to the resourcefulness with which the sultans, together with their architects and advisers, continued to profit from the legitimating force of this building type, whose status at the apex of the Ottoman architectural hierarchy endured precisely because of such readiness to depart from classical norms.

Victory without Conquest: The Sultan Ahmed Mosque and Devout Display

Notwithstanding the declinist terms in which they have sometimes seen it, scholars are justified in identifying the Sultan Ahmed Mosque as a break from established practice (figure 11.1). ${ }^{5}$ The monument caused quite the stir in its own time, for Ahmed's decision to build it was from the outset understood as problematic. The issue was twofold: having conquered no enemy territories, the sultan possessed neither the prestige for such self-commemoration nor the

3 For an extreme instance of this view, see Lewis, What went wrong? 137.

4 This discussion draws heavily on Rüstem, The spectacle, and Rüstem, Ottoman Baroque.

5 For the mosque, see Fetvacı, Music, light and flowers; Goodwin, A history of Ottoman architecture 342-349; Kuban, Ottoman architecture 361-369; Nayır, Osmanlı mimarlığında Sultan Ahmet Külliyesi 35-133; Necipoğlu, The age of Sinan 514-518. 


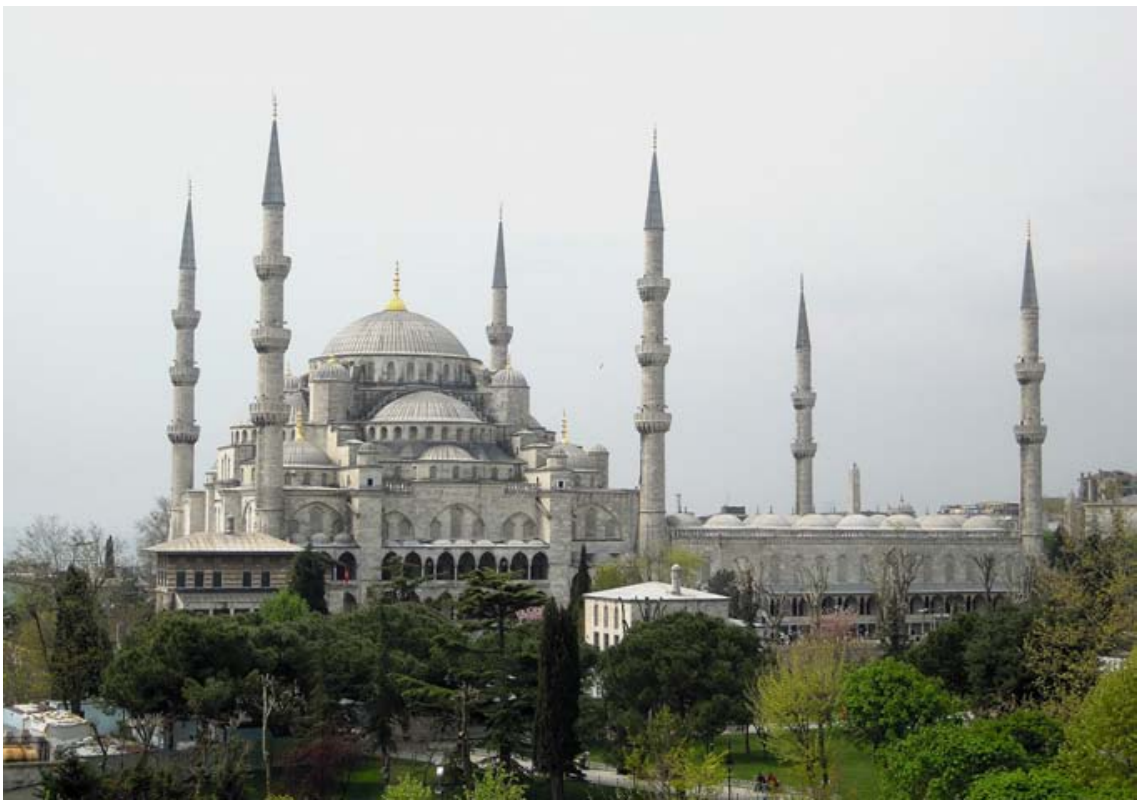

FIGURE 11.1 Sultan Ahmed Mosque, Istanbul, 1018-1026/16o9-1617, with the royal pavilion on the left protruding from the prayer hall

(C) ARNSTEIN RøNNING / WIKIMEDIA COMMONS

war booty with which to fund it. His clerics urged him to direct his resources instead toward the invasion of Christian lands, especially Crete, and the grand mufti added that the mosque's intended site next to the Hippodrome was not populated enough to necessitate a new house of worship. ${ }^{6}$ But Ahmed pushed on regardless, and though, according to the French traveler Guillaume-Joseph Grelot (d. after 1680), the mosque was initially dubbed "Imansis Gianisi" (immān$s ı$ cāmi ${ }^{s} i$ )—Mosque of the Faithless—by its detractors, ${ }^{7}$ it soon won general acceptance and even acclaim, with various contemporary and later observers extolling its superlative beauty.

The ultimately positive response to Ahmed's transgression was facilitated by numerous sympathetic voices who found ways to vindicate the project. The sultan's own imam, Muștafā Ṣâfî (d. 1025/1616), authored a eulogistic chronicle in which Ahmed is recast as a successful champion of Sunnism, particularly

6 Necipoğlu, The age of Sinan 514-515; Rüstem, The spectacle 254-256; Sâfî, Zübdetü't-tevârîh i, 51; Fetvaci, Music, light and flowers 234.

7 Grelot, A late voyage 212 (where the historical English translation is "Temple of the Incredulous"); Necipoğlu, The age of Sinan 515. 
with regard to his suppression in 1017/1608 of the rebellious Celalis, who were often branded Kızılbaş— that is, Shi'is—by their opponents. ${ }^{8}$ Implicit in Șāfi's defense is the view that the sultan's victory over heterodox rebels already qualified him as a $g \bar{a} z \bar{\imath}$ entitled to build, an opinion also recorded in a dispatch written by the English ambassador Thomas Glover (d. 1625) in late 16o9, when the foundations were being dug:

[T]he Gran Sig:r in respecte of his victorie againste the [Celali] Rebells in Asia, or in that he hath, contrarie to all mens expectations, soe suddaynlie subdued and whollie rooted them out, hath comaunded to pull downe many goodlie and sumptuous pallaces, belonginge to some of his vizereis or vizereis sonnes (payinge them well for it) and insteade therof to be builte a verie sumptuous church or Meskite, which shall be bigger then any as yet in Constant:ple and to be named by his name, Sultan Achomat. ${ }^{9}$

As if to confirm the mosque's connection to his anti-Shi'i zeal, Ahmed declared war on the Safavids shortly after the foundations were laid.

But not everyone can have been convinced that Ahmed had done enough to deserve such a monument. Glover himself gives a quite different reason for the construction in a dispatch written only a few months later, linking the project to a dangerous ailment of the throat that was causing the sultan to choke on his food. Because it was "iudged by the wiseste, that this happeneth, rather by the permition of the Allmightie, then otherwise," Ahmed felt compelled

to betake himselfe to an extraordynarie devotion, and whollie to have his conversation amongste Sofies [Sufis], and Dervishes, as much to saye, purytans ... and it is reported that this accident is the onlie cause of the buildinge of the sumptuous Meschit ... thinkinge that therby he shall, not onlie obtayne salvation of his soule, but that the Allmightie will withdrawe this dreadfull infirmitie from him, beinge therto counselled and assured, by all his above named Sofies, and his cheefe ministers, and inpticuller his Muftie; whoe sayeth to have seene a vision, or a dreame,

8 Sâfî, Zübdetü't-tevârîh i, 48. On the Ottoman authorities' attempts to smear the Celalis as heretics, see Olson, The siege of Mosul 36n82; Zarinebaf, Qizlbash "heresy."

9 Dispatch dated 22 October 16o9, The National Archives, UK (henceforth TNA), SP 97/6, 139a, quoted in Rüstem, The spectacle 257. See also Avcıoğlu, Ahmed I 219. 
that unlesse this be performed $\mathrm{w}^{\text {th }}$. a good will and harte, without any sparinge of gould or sylver, or any mans laboure, (allsoe with contynuall prayers to theire divill Mahoma, or Mahemet) the Gran Sigr. is like to incurre a verie speedie danger of his life..$^{10}$

Although Glover's account seems at first to contradict the more usual claims that the ulama advised against the mosque, the situation he describes is no less tense, with the clerics using the project almost to reprove the frightened sultan. Glover adds that these clerics assured Ahmed that, as well as curing his condition, the mosque would bring "greate and incredible victories, againste all the Gran Sig:rs enemies, whersoever he shall please to wage any warre." Even according to this account, then, the building's legitimacy was predicated on the idea that Ahmed would at least retroactively fulfill the expectation of a suitable martial victory. The conquest of Crete remained the favorite hope, but the sultan's apparent willingness to take up the challenge bore no fruit, and even the war he had launched against the Safavids came to nothing."

If Ahmed's military credentials were undeniably lacking, he and his backers were savvy to other means by which to promote the mosque, with ceremonial emerging as a major component of this campaign. It was already customary to mark constructional milestones when putting up a new imperial mosque, and much was made in particular of the foundation-laying and inauguration, which were typically celebrated with processions, thanksgiving prayers, sacrifices, and the distribution of gifts. ${ }^{12}$ With the Sultan Ahmed Mosque, however, this traditional pageantry was taken to unprecedented heights. The building was thus heralded by two foundation ceremonies, during the first of which the sultan personally dug the ground with a silver mattock. This direct and unusual act of participation not only signaled his humble devotion to the endeavor, but also alluded to a future Cretan invasion by harking back to a ninth/fifteenthcentury practice whereby the sultan would lay the first stone of his mosque before setting off on campaign. ${ }^{13}$ Ahmed's viziers and janissaries by turns followed him in the act of digging, prolonging the ceremony by a week. The

\footnotetext{
10 Dispatch dated 27 January 1610 (16o9 old style), TNA, SP 97/6, 150a-b, copied also on 151ab. Quoted in Rüstem, The spectacle 256 .

11 Necipoğlu, The age of Sinan 514, 516; Shaw, History of the Ottoman Empire 188-189.

12 For examples over the centuries, see Barkan, Süleymaniye Camive Imareti 48, 58-59; Bates, The patronage of Süleyman 67, 70; Necipoğlu, The age of Sinan 6o, 143; Neftçi, Nuruosmaniye Camii açlış töreni; Rüstem, Ottoman Baroque 123-124, 132-133; Rüstem, Victory 102-104, 112n44.

13 Necipoğlu, The age of Sinan 6o, 516; Rüstem, The spectacle 266-267.
} 
public, meanwhile, was gratified with gifts of sacrificial meat, so that all levels of society were implicated in the project from the moment of its commencement. ${ }^{14}$

Other ceremonies soon followed, including the celebration of the Prophet Muhammad's nativity, the Mevlid, in 1019/1610, when the building site was installed with cushioned sofas for the men of state and religion. In 1023/1614, while the walls were still being raised, the mosque began to host the Mevlid on an annual basis, introducing a more inclusive ceremony in which refreshments were offered to high and low alike (figure 11.2). ${ }^{15}$ The mosque's association with the Mevlid, which continues to this day, swiftly secured it a distinctive ritual profile, no mean feat in a city already teeming with religious monuments. Such use of the site also capitalized on Ahmed's reputation for uncommon piety, a trait repeatedly hailed in Muștafāa Șāfî's chronicle and other sources. ${ }^{16}$

But the most spectacular episode in the mosque's ceremonial life occurred in Jumādā II 1026/June 1617, when a grand celebration took place to mark the closing of the central dome. Held only a few months before the official opening, the dome-closing ceremony allowed Ahmed to announce the completion of his monument with far greater fanfare than afforded by the more formalized protocol of an inauguration proper. Basic details of the ceremony have long been known from the standard chronicles, where it is usually confused with the opening itself, but I was fortunate enough to stumble upon and publish an otherwise overlooked manuscript that provides a thorough monographic account of the event written within a few months of its occurrence by an anonymous author. ${ }^{17}$ While the ceremony included such expected elements as lavish giftgiving and a splendid cavalcade from and back to the Topkapı Palace, it was in other ways a highly distinctive affair. Its ostensible raison d' être - the closing of the dome- - was staged to great effect in clear view of the Hippodrome, where thousands of onlookers were treated to the sight of the dome being crowned with a symbolic capstone and a gilt crescent finial. The moment was spiritually overseen by a party of clerics and grandees whom the sultan, the manuscript tells us, had instructed to "climb and close [bağla-] the lofty dome with prayer and eulogy."18 Chief among them was the revered Sufi shaykh Maḥmūd Hüdāyī

\footnotetext{
14 Rüstem, The spectacle $266-267$.

15 Fetvacı, Music, light and flowers 237-239; Necipoğlu, The age of Sinan 516; Rüstem, The spectacle $267-270$.

16 See, for example, Sâfî, Zübdetü't-tevârîh i, esp. lxxx, 24-48; Hammer-Purgstall, Geschichte iv, 492-493; Rüstem, The spectacle $285^{-286}$.

17 Rüstem, The spectacle, where the manuscript is discussed, transliterated, translated, and reproduced.

18 Rüstem, The spectacle $267,328,337-338$.
} 


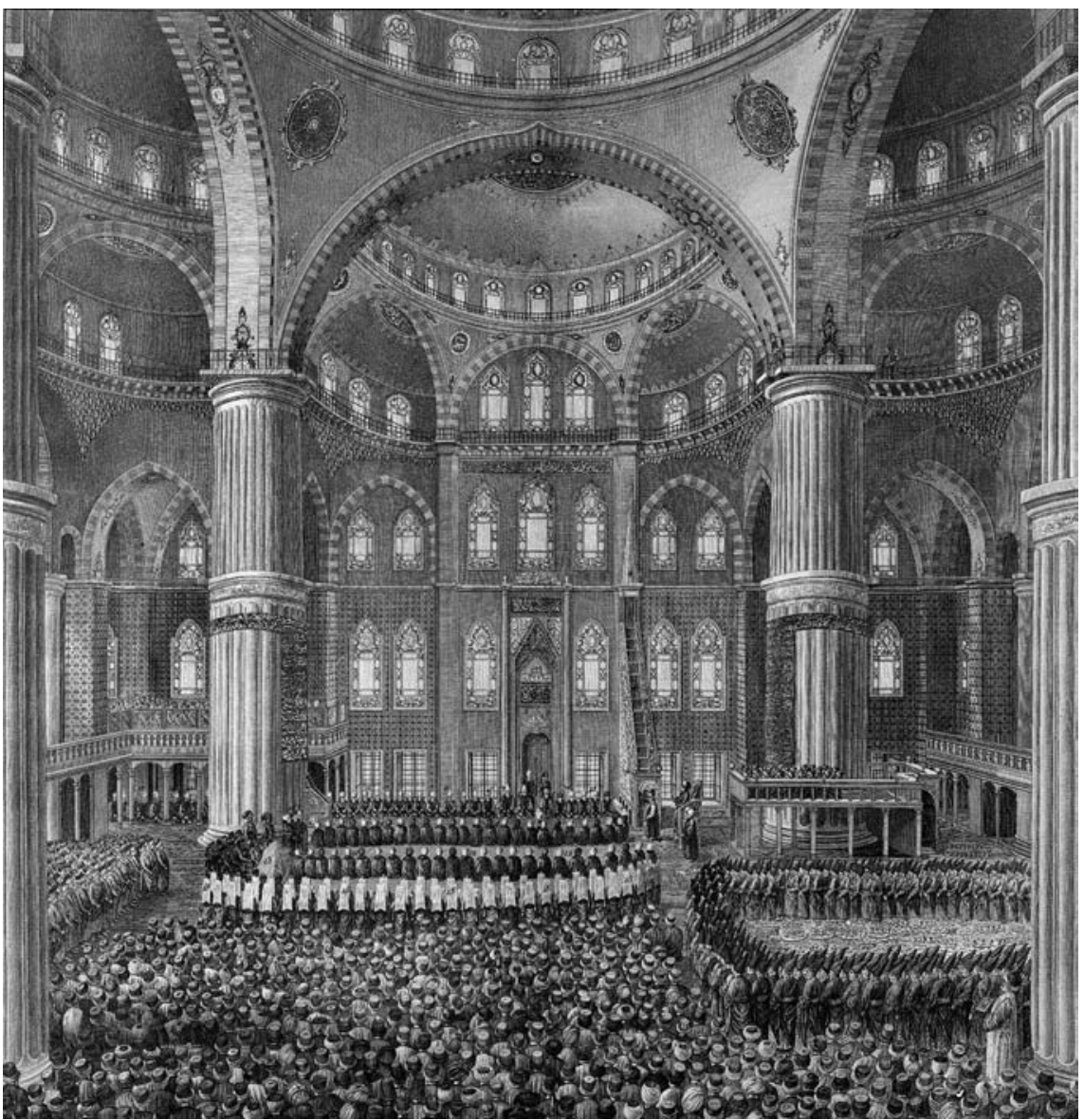

FIGURE 11.2 View of the celebration of the Prophet's nativity at the Sultan Ahmed Mosque, with the royal prayer loge at the far-left corner. By Charles-Nicolas Cochin and Née, 1787, from Ignatius Mouradgea d'Ohsson, Tableau général de l'Empire Othoman, pl. 25. Engraving on paper

COURTESY OF THE HOUGHTON LIBRARY, HARVARD UNIVERSITY

(d. 1038/1628), a religious adviser to Ahmed who had already played a leading role in earlier ceremonies at the site. ${ }^{19}$ It is unclear whether this party ascended all the way to the dome's exterior or, as is perhaps likelier, went only as far as the catwalks and galleries of the mosque's interior, which was also filled with spectators. However the episode played out, the dome's capping and consecration must have made a remarkable spectacle.

19 Ibid. 256, 266, 267, 268, 272-276. For his life and career, see Yılmaz, Aziz Mahmûd Hüdâyî. 
Another unusual aspect of the ceremony, and one scarcely less eye-catching, was the presence of tents for the sultan and his courtiers in the mosque's courtyard (probably the outer court, but the sources do not specify). Although tents were often used for Ottoman festivals, I know of no other ceremony in which a mosque precinct was turned into an encampment, and it is impossible not to read this atypical feature as a reference to warfare. Such martial symbolism defied Ahmed's critics head-on by presenting him as a victor within his own capital, and to underscore the point, his enemies too were among the ceremony's cast. As our manuscript explains,

The sultan was watched that day by the ruthless [foreign] ambassadors who were present at the assembly, and when they-despite having not a trace of faith in their hardened hearts - saw the selfless favor that the magnanimous sultan conferred on the people of the world, together with the good works and pious deeds done in the path of God ... countless infidels could not help but come to Islam ... And even the remaining wicked infidels could not help but say countless prayers for the life and state of the sultan ... and whether the ambassador of the reprobate Kuzllbaş or whether Venetian, Fleming, or Frank — they are one scourge alike—all of them were frustrated and confounded. ${ }^{20}$

This dense narrative requires some clarification. Though conflated with the reference to foreign ambassadors, the mention of infidels adopting Islam must pertain to Ottoman non-Muslims who may have converted during the ceremony, as we know happened at other public festivals. ${ }^{21}$ As for the "Kızlbaş" ambassador, he was, of course, the Safavid representative, who is treated as no less of an unbeliever than his Christian counterparts. ${ }^{22}$ This equation builds on the idea that Ahmed's fight against Shi'ism — epitomized by his quashing of the Celalis - merited the same approbation as a war against a Christian foe.

Without explicitly telling us, the manuscript gives the impression that the ambassadors were not merely present but officially accommodated at the ceremony, and this is confirmed by a dispatch written by the Venetian bailo Almorò Nani (d. 1633), who was among the representatives. We learn from his

20 Rüstem, The spectacle $286,330,339-340$ (quoted with minor orthographic changes).

21 For examples of this phenomenon, see Terzioğlu, The imperial circumcision festival 85; Baer, Honored by the glory 179-203, 293n31. It is significant to note that Ahmed's reign saw the development of a special kind of conversion ritual at the Imperial Council: see Krstić, Illuminated 58 .

Cf. Terzioğlu, The imperial circumcision festival $85-87$. 
account that he and the English, Dutch, French, and Habsburg ambassadors were invited to attend the ceremony and provided with their own specially built viewing loggia opposite the mosque on the other side of the Hippodrome. ${ }^{23}$ Nani says nothing of the Safavid envoy, who may have been permitted a spot within the mosque precinct despite his "reprobate" status. As for the European ambassadors, their orchestrated presence at the event appears to have been extremely unusual by the standards of other Ottoman mosque ceremonies and was clearly vital to the event's meaning. In the context of so much religiously charged display, the vastly outnumbered Christian dignitaries served as the event's symbolic antagonists, subjugated by all that was happening around them. This "us-and-them" setup no doubt hinted at the possibility of future warfare, but the ceremony's real success lay in its glorification of the mosque itself as an achievement already equal to any Muslim conquest, one that could, as the manuscript asserts, overwhelm the "hardened hearts" even of foreign infidels. Invoking Ahmed's widely lauded religiosity, the conceit would have been verbalized after the blessing of the dome by Maḥmūd Hüdāyī, who Nani tells us gave a sermon "praising the sultan's goodness and then reproving the general injustice and rapacity of [his] enemies."24

The most vivid proof of this goodness was, of course, the mosque itself, whose undeniable splendor gave convincing form to the rhetorical and ceremonial claims being made for it (figure 11.1). Although criticized by modern art historians as an ostentatious reiteration of the classical Ottoman manner, ${ }^{25}$ the Sultan Ahmed was in its own time widely praised. Evliyā Çelebi (d. 1095/1684?), for instance, tells us that "the graciousness of its architectural style is unknown in the mosques of other countries," ${ }^{26}$ a sentiment echoed by Grelot, who deemed the mosque "the most beautiful in Constantinople, if not in all the East." ${ }^{27}$ The monument's architect, Ședefkār Meḥmed Agha (d.

23 Dispatch dated 13June 1617, State Archives of Venice, Senato, Dispacci Costantinopoli, filza 83, 15/II, 211a-221b, translated and transliterated in Rüstem, The spectacle 286-287, 297$298 n 162$.

24 Rüstem, The spectacle 287.

25 Goodwin, A history of Ottoman architecture 344.

26 Evliyâ, Seyahatnâme i, 87, quoted and translated in Necipoğlu, Challenging the past 177; Fetvacı, Music, light and flowers 224. Despite this high praise, the claim that Evliyā describes the Sultan Ahmed as "the most beautiful of all the sultanic mosques in Istanbul" is an erroneous one that, as Robert Dankoff and Semih Tezcan have pointed out, is based on a misleading late thirteenth/nineteenth-century transcription of the original text. The mistake regrettably appears in my own article on the dome-closing ceremony. See Dankoff and Tezcan, Evliya Çelebi bibliography 4; Rüstem, The spectacle 26 o. 
ca. 1031/1622), was a student of the famous Sinān (d. 996/1588), whose Süleymaniye Mosque was the Sultan Ahmed's immediate forerunner. ${ }^{28}$ As Emine Fetvacı has discussed, Mehmed Agha skillfully adapted his master's manner to create something that referred to the empire's Süleymanic heyday even as it spoke to eleventh/seventeenth-century tastes. ${ }^{29}$ With its elephantine piers, four semidomes, six minarets, and lavish tilework, the Sultan Ahmed eschews the more restrained grandeur of the Süleymaniye in favor of unbridled pomp. This approach also allows the mosque to hold its own against the Hagia Sophia, which faces it from across an open square. While much smaller than the erstwhile cathedral, the mosque outdoes it in terms of aesthetic coherence and elegance, thus earning its place in this most central and privileged of locations. Few among the sultan's Muslim subjects can have failed to see the monument as a magnificent sign of God's favor.

The multipronged effort that went into selling Ahmed's enterprise shows how mindful he and his advisers were of established codes even as they were redefining them. After all, the justifications put forward for the mosque still centered on the idea that the sultan had won the right to build by advancing the cause of Islam. The earlier tactic - that of treating the defeat of (supposedly Kızılbaş) Celali insurgents as tantamount to a victory over infidels-reflected what Derin Terzioğlu has characterized as a "greater expectation of confessional exactitude in matters of [Ottoman Sunni] doctrine and ritual as well as a heightened concern with social discipline" during the sixteenth and early seventeenth centuries, when the Ottomans were busy fighting their (Shi ii) Safavid neighbors. ${ }^{30}$ But it was ultimately Ahmed's own exemplary Sunnism that was weaponized as his chief credential, further widening the traditional conception of "campaigns of the Faith" to include even nonmilitary deeds. ${ }^{31}$ Built for the glory of the religion, the mosque in a sense became its own vindication, and thereby the sultan's too.

Such spin was part of a broader shift in the ruler's image that began around these years. In contrast to their more aloof predecessors, Ahmed and the sultans who followed him generally tended toward a less remote style of kingship, making themselves more visible and — notionally, at least—accessible to their

28 For an architectural treatise centered on Mehmed Agha's career and written during the construction of the Sultan Ahmed Mosque, see Cacfer, Risāle. On Ahmed's identification with Süleymān, see Avcıoğlu, Ahmed I, esp. 218-220.

29 Fetvac1, Music, light and flowers.

30 Terzioğlu, How to conceptualize 318.

31 The term "campaigns of the Faith" ( $\dot{g} a n a \bar{y} y i m-i$ cihād) is borrowed from Muștafâ 'Ālī: see 'Ālī, Counsel i, 54, 146, quoted in Necipoğlu, The age of Sinan 6 o. 


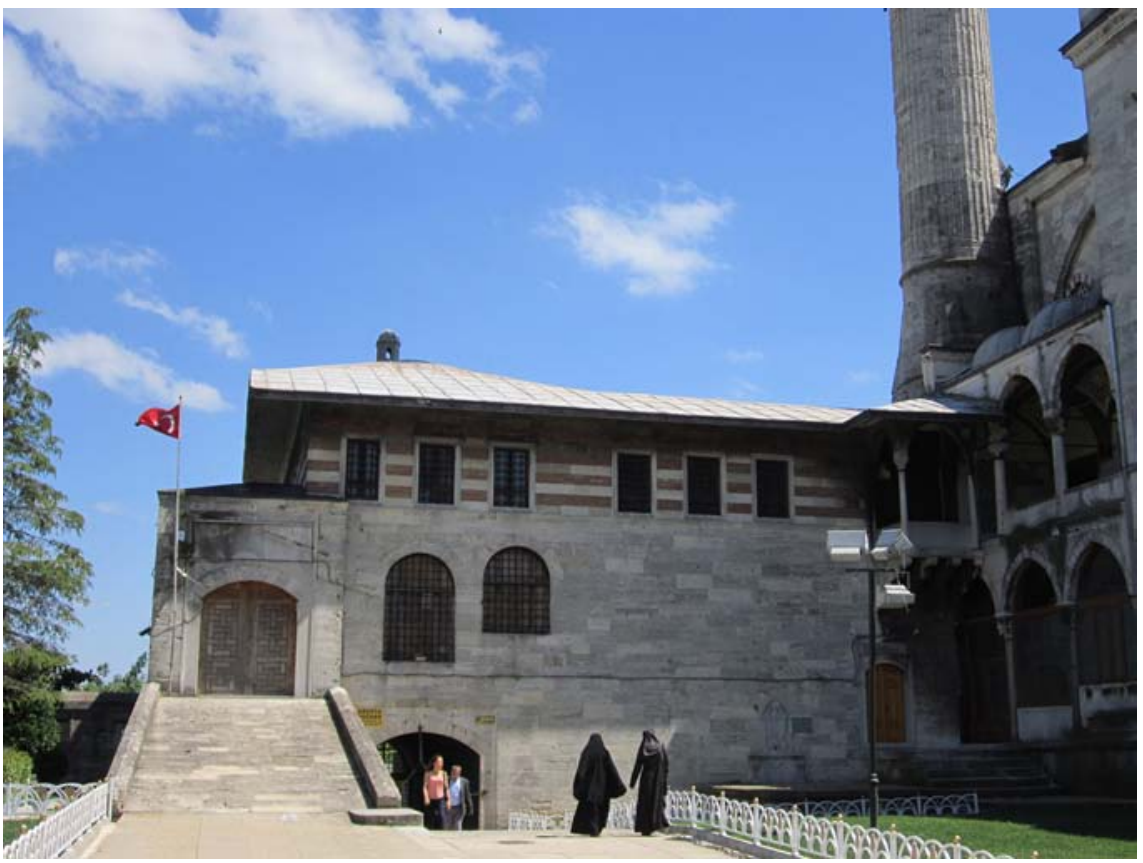

FIGURE 11.3 Sultan Ahmed Mosque, royal pavilion viewed toward its entrance side, with the attached mosque on the right PHOTO COURTESY OF GÜVEN ERTEN

subjects. ${ }^{32}$ The desire to raise the sovereign's profile in this way must have been spurred in part by the diminishment of his once invincible military aura, but the result was far from defeatist. On the contrary, the Ottoman state succeeded in cultivating a new kind of reputation for the sultan that foregrounded his benevolent presence among his people as God's shadow on earth. The vibrant ceremonial activity surrounding the Sultan Ahmed Mosque was very much part of this new manner of kingly conduct, and the monument also introduced a more concrete means of facilitating the sultan's self-display: a pavilion attached to the mosque's eastern corner (figures 11.1 and 11.3).

Entered by a ramp and containing an elevated suite of rooms, this L-shaped structure gives access to the sultanic loge inside the neighboring prayer hall (figure 11.2). ${ }^{33}$ It is the first example of a building type that would come to be known as the kașr-ı hümāyūn (hünkâr kasrı in modern Turkish), or royal

32 Hamadeh, The city's pleasures 50-52; Necipoğlu, The age of Sinan 516; Rüstem, Ottoman Baroque 126-128, 133-137.

33 For this structure, see Kuban, Ottoman architecture 365-369; Nayır, Osmanlı mimarlığında Sultan Ahmet Külliyesi 78-79; Rüstem, The spectacle 262-268. 
pavilion, a name that accurately captures its function as a miniaturized palace designed to host Ahmed and his successors before and after their visits to the mosque. ${ }^{34}$ Its brick-and-stone walls and hipped roofs are at once a mark of its status - they follow the norms of palatial architecture-and a decorous concession to the adjacent mosque, whose domes, ashlar walls, and scale make the far smaller pavilion seem almost like a latterly added afterthought. Contrary to this impression, the pavilion had its origins in a structure erected at the very start of the project to accommodate Ahmed whenever we came to view the building site. ${ }^{35}$ As the prayer hall took shape, certain parties must have realized the long-term potential of turning this structure into a permanent pavilion for use during royal visits, and especially the Friday parade, when the sultan would set out from the Topkapı Palace in stately procession to attend the midday prayer in one of the city's imperial mosques. These regular public outings afforded the populace not only sight of their ruler, but also, in theory, recourse to his protection, as the sultan's guards would collect petitions from the watching crowds. ${ }^{36}$ The Friday parade thus brought the splendor of the court and the justice of the Imperial Divan - another venue for petitioners - out into the city itself, connecting palace and mosque in a powerful statement of the sultan's God-given authority. Even with the procession's longstanding grandeur, however, sultans before the eleventh/seventeenth century would reach their prayer loges through nothing more than a discreet private entrance. The pavilion at the Sultan Ahmed Mosque redressed this deficiency by providing the parade with its own architectural climax, one that gave solid expression to the idea of the ceremony as a nexus between the courtly, public, and spiritual spheres. What made this symbolism all the more potent was that it endured long after the impact of the royal visits themselves had subsided, implying the sultan's presence even in his absence. So effective was the feature that all subsequent imperial mosques would include it, a tangible demonstration of the sultan's increasingly public face.

34 For the history of this feature, see Kuran, The evolution of the sultan's pavilion; Rüstem, Ottoman Baroque 125-129; Tanman, Kasr-ı hümâyun. For an alternative view of its origins, see Thys-Şenocak, The Yeni Valide Mosque (as discussed in footnote 45 below). Gontaut-Biron, Ambassade ii, 372; Sâfî, Zübdetü't-tevârîh i, 52; Necipoğlu, The age of Sinan 516 .

36 Boyar and Fleet, A social history of Ottoman Istanbul, 31, 37-39; İpşirli, Osmanlılarda Cuma selâmlı̆̆ $463-466$. 


\section{New Approaches for Changing Times: The Emergence and Impact of the Nuruosmaniye Mosque}

Despite Ahmed's personal achievement in overcoming the traditional restrictions, his successors trod rather more carefully, and it would take over a century for a sultan to build another mosque in the capital. This apparent reticence suggests a return to a more normative understanding of the sultanic mosque's significance, with glorious victory in holy war reasserting itself as a prerequisite — or at least desideratum - for royal self-commemoration. But if Ahmed had failed to amend earlier codes, his project seems nonetheless to have encouraged the pursuit of further alternative strategies in its wake. One such strategy was for the grandest level of patronage to be taken up by the vālide sulțāns, queen mothers, who, as well as being exempt from any expectation of martial valor, were also growing in power during this period. And so it was Hadīce Turhān (d. 1094/1683), mother of Mehmed IV (r. 1058-1099/16481687, d. 1104/1693), who erected Istanbul's other great eleventh/seventeenthcentury foundation, the Yeni Cami in the busy shoreline district of Eminönü (figure 11.4). ${ }^{37}$ Inaugurated in 1076/1665, the mosque had in fact been initiated as far back as 1006/1597 by another queen mother, Șāfiye Sultan (d. 1028/1619), but was abandoned when she lost her rank upon the accession of her grandson Ahmed. The walls of Șâfiye's mosque reached only as high as the lower windows when work was halted, and the site soon became covered over with houses and debris. ${ }^{38}$ It was not until the great fire of 1070/166o destroyed these dwellings that construction resumed under the patronage of Hadīce Turhān Sultan, who is said to have been touring the district with the aim of helping its people when she first noticed the mosque's aborted walls. ${ }^{39}$ Where Saafiye had faced strong criticism for her legally dubious expropriation of the site, Hadīce Turhān was praised for making good the enterprise and piously regenerating Eminönü, such that - to use Evliyā Çelebi's terms—a mosque of oppression (zulmiyye) was turned into one of justice ('adliyye). ${ }^{40}$

37 For this mosque, see Ateş, İstanbul Yeni Cami; Nayır, Osmanlı mimarlığında Sultan Ahmet Külliyesi 137, 135-168; Thys-Şenocak, Ottoman women builders 186-257, 272-274; ThysŞenocak, The Yeni Valide Mosque.

38 Nayır, Osmanlı mimarlığında Sultan Ahmet Külliyesi 136-137; Thys-Şenocak, The Yeni Valide Mosque at Eminönü 63-64.

39 Nayır, Osmanlı mimarlığında Sultan Ahmet Külliyesi 137; Thys-Şenocak, The Yeni Valide Mosque complex at Eminönü 66.

40 Thys-Şenocak, The Yeni Valide Mosque complex at Eminönü 63-68. For Evliyā's account of the mosque, see Evliyâ, Seyahatnâme i, 302, as quoted and discussed in Thys-Şenocak, The Yeni Valide Mosque complex at Eminönü 68, 7on48. 


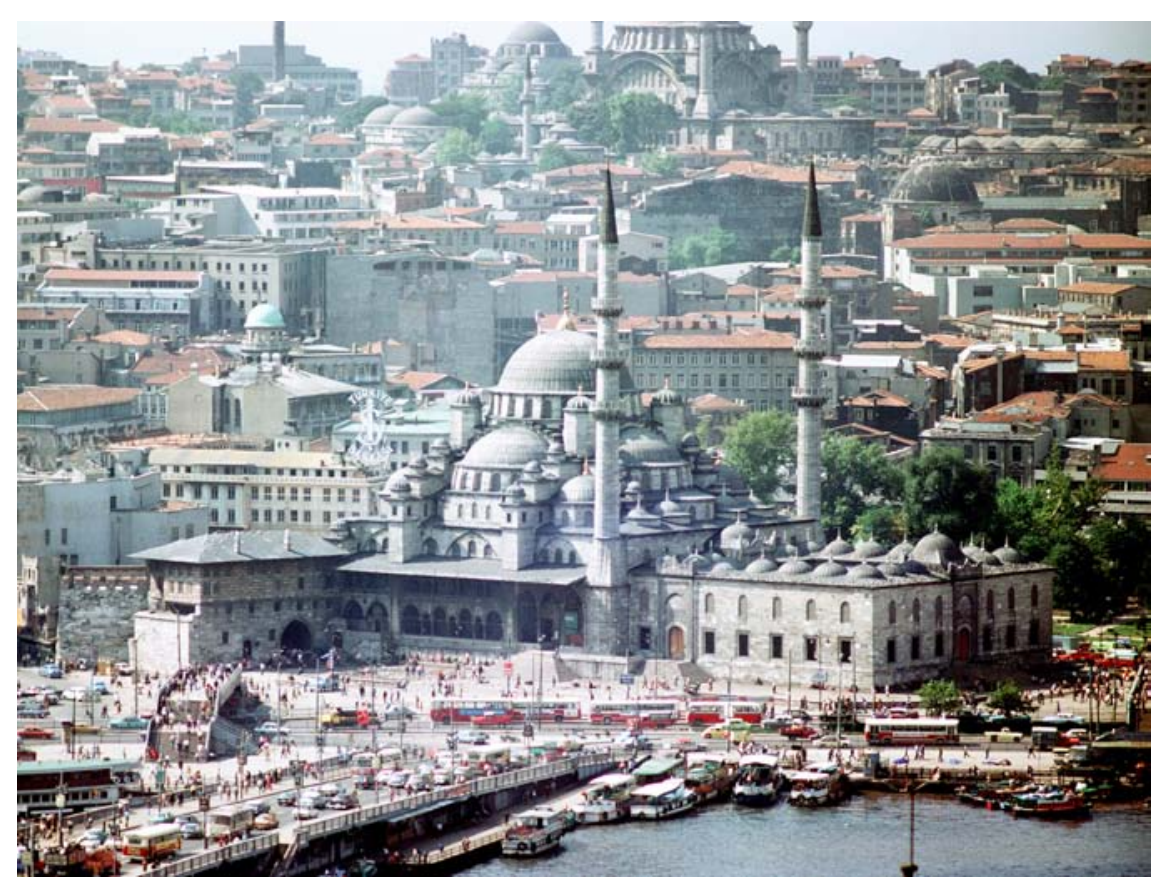

FIGURE 11.4 Yeni Cami, Istanbul, 1006-1076/1597-1665, with the royal pavilion on the left protruding from the prayer hall

(C) JEAN-PIERRE BAZARD / WIKIMEDIA COMMONS

This narrative of redemption was fueled by the fact that most of the inhabitants of the site had been Jewish, which allowed the Islamization of Eminönü to be regarded as a sort of conquest in its own right. Already operative during the initial phase under Șâfiye, ${ }^{41}$ the anti-Jewish sentiment surrounding the project would have intensified in the sociopolitical climate of the mideleventh/seventeenth century, when the zealous and puritanical Kadızadeli movement exercised considerable influence in Istanbul, including in Hadīce Turhān's own circle. ${ }^{42}$ Something of the Kadızadelis' hostility toward the dhimmi communities may be reflected in a later account by the chronicler Silāḥdār Meḥmed Agha (d. 1139/1726-1727), who, with reference to Eminönü's demographics and general dilapidation, wrote, "The abominable condition of the area was an affront to the religion and the state; the comple-

41 Thys-Şenocak, The Yeni Valide Mosque complex at Eminönü 61-63, 64 .

42 Ibid. 66-68. For the Kadızadeli context, see Zilfi, The politics of piety 129-181. 


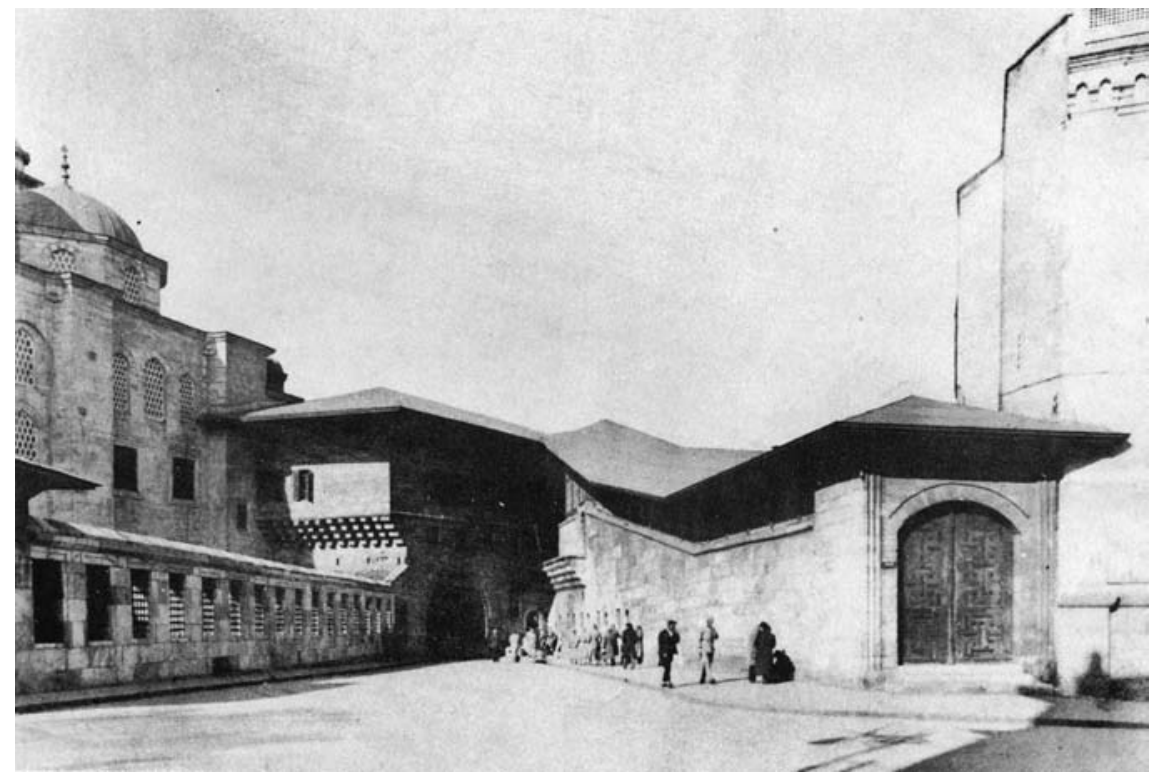

FIGURE 11.5 Yeni Cami, royal pavilion viewed toward its entrance ramp, with the attached mosque on the left PHOTO FROM IBRAHIM ATEŞ, ISTANBUL YENI CAMİ VE HÜNKAR KASRI [ISTANBUL, 1977?], FIG. 39

tion of the mosque would guarantee prayers for the valide until the time of the Resurrection." 43

Like the Sultan Ahmed, Hadīce Turhān's mosque is (from the perspective of eleventh/seventeenth-century audiences) a modernized reworking of the classical manner, its central dome loftier in profile than its tenth/sixteenthcentury counterparts and its interior more lavishly tiled. Here, the royal pavilion has grown into a truly substantial brick-and-stone building entered by a monumental ramp that the sultana is said to have ascended by means of a palanquin (figure 11.5). The rooms to which the ramp leads survive with much of their palatial splendor intact. ${ }^{44}$ Lucienne Thys-Sुenocak has linked the scale and arrangement of the pavilion to Hadīce Turhān's status as a female patron: as well as providing a venue for her entourage, the building would have given her visual access to, and symbolic dominance over, parts of the complex that a

43 Quoted in Thys-Sुenocak, The Yeni Valide Mosque complex at Eminönü 66.

44 For the pavilion, see Ateş, İstanbul Yeni Cami 17-46; Kuran, The evolution of the sultan's pavilion 281-282; Nayır, Osmanlı mimarlığında Sultan Ahmet Külliyesi 157-159; ThysŞenocak, Ottoman women builders 220-237; Thys-Şenocak, The Yeni Valide Mosque; Yücel, Yeni Cami hünkâr kasrı. 
royal woman could not enter. ${ }^{45}$ She is, moreover, recorded as having used the pavilion as a vantage point from which to survey the building work, recalling Ahmed's visits to his pavilion earlier in the century. ${ }^{46}$ The structure thus stood as a conspicuous testament to the queen's munificent supervision.

But as much as the Yeni Cami became Hadīce Turhān's gift to the city, it was also designed to be used by her son, Mehmed, and it is he rather than the queen mother who is eulogized in a poem that decorates the pavilion's interior. The verse hails Mehmed as the sultan "who has subdued all" and whose "rule is full of conquests from the beginning to the end," likening him to Süleymān the Magnificent and the legendary hero Rustam. ${ }^{47}$ Mehmed's military record had, in reality, been a mixed bag up to this point, though his reign would soon see a number of impressive Ottoman victories-including the conquest of Cretethat brought the empire to its greatest territorial extent in Europe. ${ }^{48}$ Even so, Mehmed could not yet confidently claim a gāzī's prerogative when the Yeni Cami was resumed, and the mosque must to some extent have been intended as a workaround, with the mother using her own wealth and entitlement to build something that might also serve as a monument to her son. ${ }^{49}$ Although the seeds of this solution had been sown long before by Ṣâfiye, ${ }^{50}$ the likelihood of its success had grown by the mid-eleventh/seventeenth century in tandem with the stature of the queen mother herself. Hadīce Turhān in particular often acted as her son's proxy, representing him in the capital during his frequent retreats to Edirne. ${ }^{51}$ A physical outcome of this arrangement, the Yeni Cami likewise assumed the role of a substitute for what the sultan had left unperformed.

A still stronger conflation of mother and son would occur with the mosque of another vālide sulțān, Emetu'llāh Rābi'a Gülnūş (d. 1127/1715) (figure 11.6). Located in Üsküdar and completed in 1122/1710, the Yeni Valide Mosque has

Thys-Şenocak, The Yeni Valide Mosque, esp. 74-77. I do not agree with Thys-Şenocak's assertion that the early eleventh/seventeenth century witnessed no significant ceremonial changes to explain the advent of the royal pavilion at the Sultan Ahmed Mosque and that the feature may therefore have originated as a gendered space in the Yeni Cami's original design. As I have discussed above, the Sultan Ahmed Mosque was from the outset associated with highly augmented ceremonial practices that provide a logical context for the pavilion's introduction there.

46 Goodwin, A history of Ottoman architecture 357; Necipoğlu, The age of Sinan 512.

47 Translated by Hakan Karateke in Thys-Şenocak, Ottoman women builders $220-222$.

48 Shaw, History of the Ottoman Empire 209-213; Thys-Şenocak, Ottoman women builders 218.

49 Thys-Sुenocak, Ottoman women builders 218, 222-224.

$5^{\circ}$ Thys-Şenocak, The Yeni Valide Mosque 64.

$5^{1}$ Thys-Şenocak, Ottoman women builders 104-106, 269-270. 


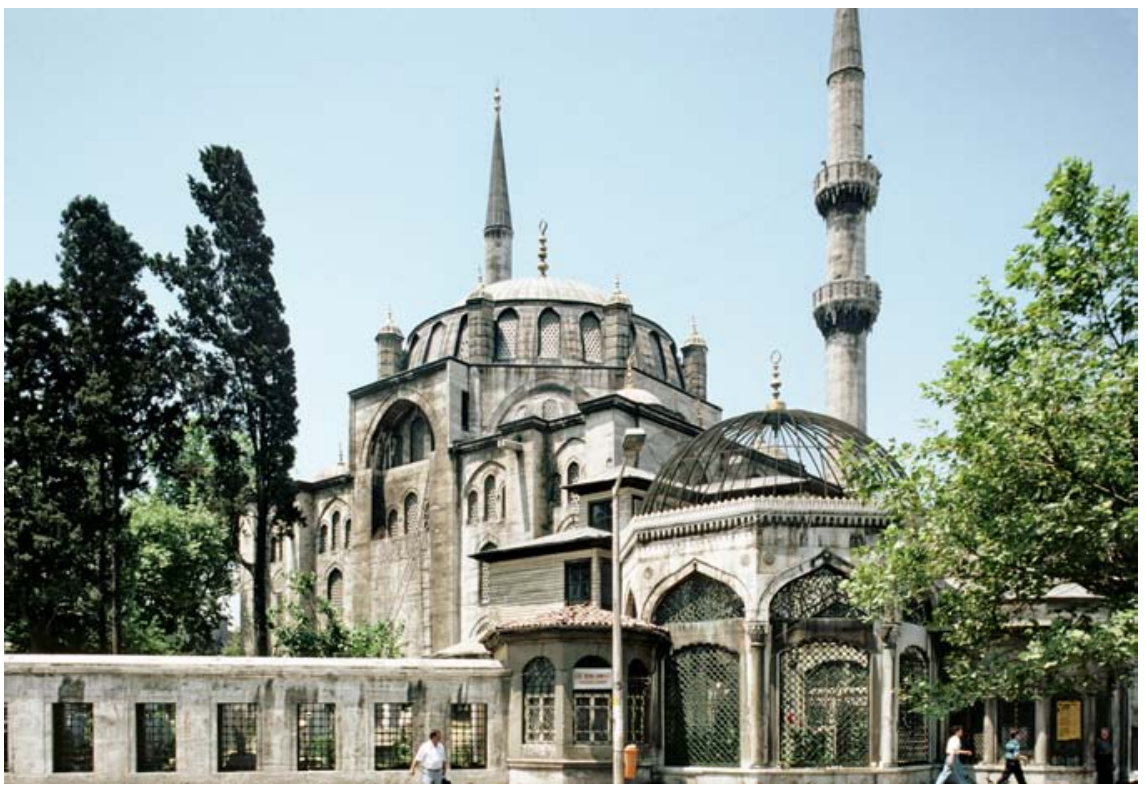

FIGURE 11.6 Yeni Valide Mosque, Üsküdar, Istanbul, 1120-1122/1708-1710 PHOTO COURTESY OF WALTER B. DENNY

since the late twelfth/eighteenth century been misattributed to Gülnūşs son Sultan Ahmed III (r. 1115-1143/1703-1730, d. 1149/1736), who is said to have built it in her honor. ${ }^{52}$ But the period's official chronicler, Rāşid, as well as the mosque's own inscriptions leave us in no doubt that Gülnūş herself was the patron, even if the building was meant to stand in for her son too. ${ }^{53}$ Installed on the throne through a revolution in 1115/1703, Ahmed III is famous for presiding over Istanbul's reinvigoration following a long absence by the court, which had been based in Edirne for much of the preceding half century. ${ }^{54} \mathrm{He}$ fared less well on the international stage, however. His reign followed on from the aftermath of the disastrous Ottoman defeat at Vienna in 1094/1683, which spelled an end to

52 For the mosque, see Ayvansarāyī, The garden of the mosques 493-494; Goodwin, A history of Ottoman architecture 365-366; Haskan, Yüzyıllar boyunca Üsküdar i, 379-391; Kuban, Ottoman architecture 384-386; Özgüleş, The women who built 157-184. Of these authors, all but Haskan and Özgüleş erroneously credit the mosque to Ahmed III, as too does Crane (The Ottoman sultan's mosques 189).

53 Râşid and Âșım, Târih-i Râşid ii, 797, 848-849; Haskan, Yüzyıllar boyunca Üsküdar i, 38o382, 387-388.

54 For the architectural boom that that followed the court's return in 1115/1703, see Artan, Architecture as a theatre of life; Artan, Istanbul; Hamadeh, The city's pleasures, esp. 17-75; Rüstem, Ottoman Baroque 20-55. 
the empire's expansion, and though his armies were able to recover certain territories from the Venetians, he was compelled to cede Serbia to the Habsburgs in $1130 / 1718 .{ }^{55}$ Little wonder, then, that an imperial mosque was not among the numerous architectural works that Ahmed bestowed upon Istanbul after the court's return, and it was once again through the surrogacy of a queen mother that such a foundation came to be built.

That Ahmed was able to profit so fully from his mother's mosque-even to the point of being latterly credited with it - was in part because of its location. Being outside the walled peninsula, and on the Asian side to boot, Üsküdar was not part of Istanbul strictly defined, and this points to another factor determining the decorousness of sultanic construction. Although Muștafā 'Ālì does not qualify his advice geographically, it seems that the conditions he outlines were felt to apply above all to the capital. Murād III may have stopped short of erecting a mosque in Istanbul, but he did not hesitate to have Sinān construct one in Manisa (991-994/1583-1586), replacing an earlier-and smaller-mosque he had built while a prince in that city. ${ }^{56}$ Even Sinān's celebrated masterpiece, the Selimiye (976-982/1568-1574), may have been affected by locational concerns: despite presiding over a number of Ottoman victories, Selìm II (r. 974-982/1566-1574) did not personally lead the army as his father, Süleymān, had done, and this, as Gülru Necipoğlu has suggested, may partly explain why his foundation was built in Edirne rather than Istanbul. ${ }^{57} \mathrm{As}$ we are about to see, the limiting of the regulation to the capital — that is, the walled city—seems to have become codified by the twelfth/eighteenth century, and it was perhaps partly out of regard for this opinion that Gülnūş, knowing her mosque would be identified with her son, chose to build it in Üsküdar.

A more forthright approach could be taken by Ahmed's immediate successor, Mahmūd I (r. 1143-1168/1730-1754), whose now rather unremarkable reputation belies the high esteem in which he was held during the twelfth/eighteenth century. Following a shaky start, Mahmūd emerged as a capable ruler both domestically and in the international arena. His standing was secured in 1152/1739 when his army, following years of war with both the Austrians and the Russians, defeated the former in Belgrade, winning back Serbia. The ensuing peace treaty with the Habsburgs compelled Russia to sign a treaty of its own, ending the war in the Ottomans' favor. An unprecedented thirty years of peace

55 Finkel, Osman's dream 253-333.

56 Necipoğlu, The age of Sinan $25^{6-265}$.

57 Ibid. $65^{-66 .}$ 


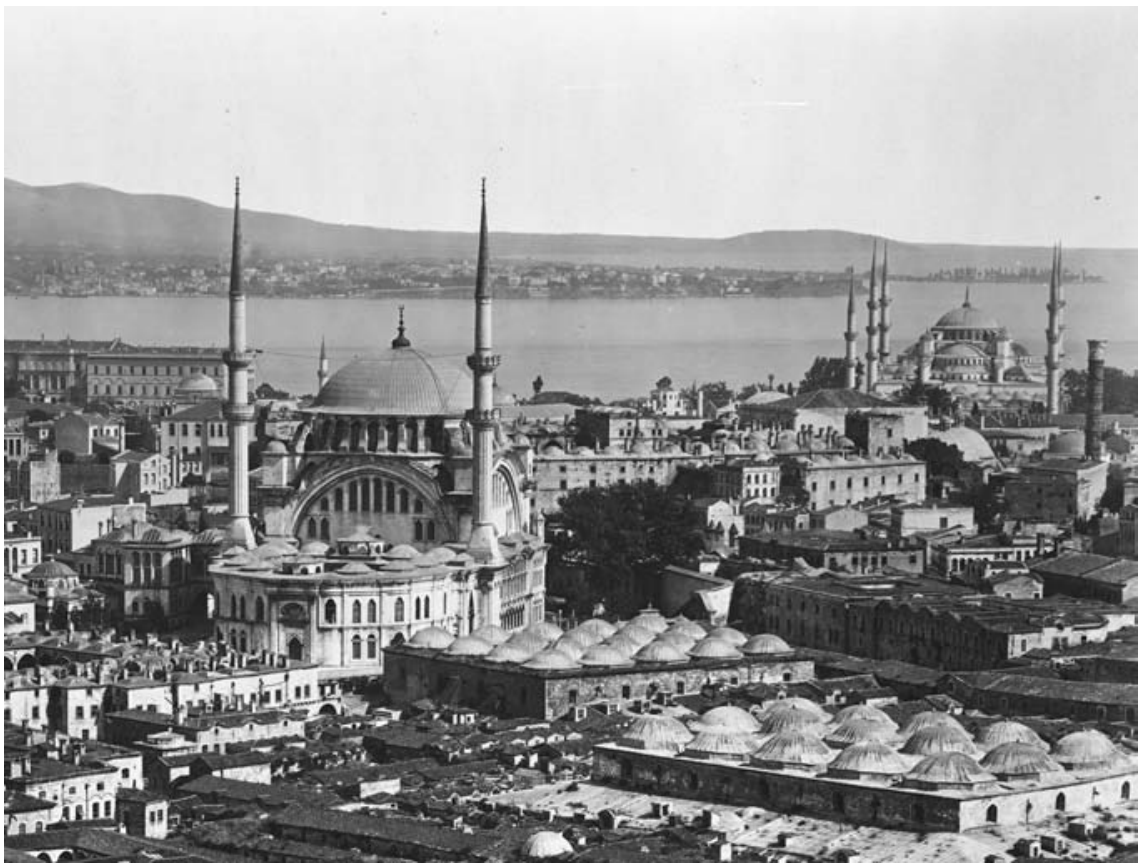

FIGURE 11.7 Nuruosmaniye Mosque, Istanbul, 1161-1169/1748-1755, aerial view, with the Grand Bazaar in front and the Sultan Ahmed Mosque in the right background. Photographed by 'Alī Riżā' Bey, ca. 188os. Albumen print LIBRARY OF CONGRESS, WASHINGTON, DC. PRINTS AND PHOTOGRAPHS DIVISION, ABDUL HAMID II COLLECTION [LC-USZ62-78322]

would follow between the empire and its Christian neighbors. ${ }^{58}$ Having already shown himself to be a keen patron of the arts, ${ }^{59}$ Mahmūd wished to mark his empire's good fortune by building a new royal mosque complex in the capital, the first to be established by a sultan since the Sultan Ahmed. Work on the monument began in 1161/1748 and reached completion in 1169/1755, shortly after Mạ̣mūd's death and a year into the reign of his brother 'Oșmān III (r. 1168-1171/1754-1757), who claimed the building as his own and named it Nuruosmaniye - both "Light of the Ottomans" and "Light of 'Ossmān” —in dual reference to himself and the dynasty (figure 11.7). ${ }^{60}$

$5^{8} \quad$ For overviews of these events, see Finkel, Osman's dream 355-371; Aksan, Ottoman wars 102-128.

59 Keskiner, Rüstem and Stanley, Armed and splendorous; Rüstem, Ottoman Baroque 6o-63, 68-82, 97-103.

6o For the mosque, see Goodwin, A history of Ottoman architecture 382-387; Hochhut, Die Moschee Nûruosmâniye; Kuban, Ottoman architecture 526-536; Rüstem, Ottoman Baroque 111-169; Sav, Nuruosmaniye Camii; Suman, Questioning an "icon of change." 
As we shall see, Mahmūd's decision to bring the imperial mosque back to life would rejuvenate the genre as whole, sparking a new boom in the sultans' own patronage of religious foundation for the next century and a half. ${ }^{61}$ This revival has received surprisingly little attention in the scholarship, which has tended to discuss late Ottoman architecture with reference to secular works that both reflect and reaffirm the notion that the postclassical period witnessed a decline in the sultanic mosque's cachet. Consistent as this view may seem with the many institutional and cultural changes that indeed transformed the empire in its final two centuries, the Nuruosmaniye and its heirs demonstrate that even the most traditional of building categories could flourish hand in hand with artistic novelty and broader processes of institutional modernization. ${ }^{62}$ Not only did the sultanic mosque remain meaningful in this shifting context, but it managed to reassert its preeminence in ways that continued to invokealbeit differently from before-the ruler's status as defender and promoter of Islam.

The religiously and politically charged circumstances in which the Nuruosmaniye came into being are explained in a letter by Claude-Charles de Peyssonnel (d. 179o), a French consul and long-time resident of the Ottoman Empire: "The Sultan, before he can build a Temple, within the walls of Constantinople, must have gained some victory over the enemies of the Empire, or have extended the Ottomans possessions, and thereby merited the surname of Gazi, or Conqueror. Sultan Mahmoud, who had legally acquired this right, by gaining the battle of Grosca [Grocka], against the Germans, and taking Belgrade, never thought of building a Mosque at Scutari, but erected a very beautiful one within the capital." ${ }^{63}$ Written by someone well acquainted with Ottoman custom, these words prove not only that the codes inherited from earlier centuries still carried considerable weight, but that they had been further refined to explicitly address the issue of location. Crowning Istanbul's second hill and situated in a prime spot next to the Grand Bazar, the Nuruosmaniye replaced a smaller nonroyal mosque that had fallen into disrepair, and so claimed the last

61 For an overview of these later mosques, see Crane, The Ottoman sultan's mosques 189191. For this boom as it played out in the twelfth/eighteenth century, see Rüstem, Ottoman Baroque.

62 Indeed, my book on the architectural transformation of twelfth/eighteenth-century Istanbul centers on these mosques precisely because of their value as case studies. See Rüstem, Ottoman Baroque, esp. 1-4, 13 .

63 Peyssonnel, Strictures and remarks 194-195. For Peyssonnel's biography, see Depincé, Compte i, 158-162. His letter ("to the Marquis de N.") appears as a lengthy corrective appendix to the second edition of the memoirs of François de Tott (d. 1793), a French aristocrat of Hungarian origin who served as a military adviser to the Ottomans. 
available spot on Istanbul's intramural skyline. ${ }^{64}$ Much buzz surrounded the building, and the project's financial secretary, a certain Ahmed Efendi, penned a rare and lengthy account of its construction, the History of the noble mosque

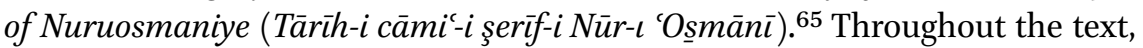
Ahmed Efendi emphasizes Mahmūd's divinely inspired purpose in building the mosque, even referring to a chance encounter with a sage who supposedly inspired the sultan to enlarge the scheme. ${ }^{66} \mathrm{He}$ does not, however, mention the Ottomans' success at Belgrade as a reason for the project, and while this may seem to undermine Peyssonnel's explanation, it should be borne in mind that the text was written under Sultan 'Oșmān, who could take no credit for the conquest and who tried in other ways to disassociate the mosque from his brother. ${ }^{67}$ Notwithstanding the silence of the official discourse, then, Peyssonnel's account surely reflects a wider interpretation of the mosque as Mahmūd's victory monument.

The Nuruosmaniye's triumphal message was redoubled by its novel appearance (figure 11.7). Although its construction harked back to historical precedent, the mosque looks quite unlike any of its forerunners. Its single dome, set high on four enormous arches, stands in contrast to the pyramidal vaulting typical of earlier mosques, and the semielliptical rather than quadrangular shape of its courtyard is a yet bolder departure from tradition. Even the choice of architect - an unconverted Greek named Simeon Kalfa_-broke with custom. ${ }^{68}$ Confirming the sense of newness is the mosque's exuberantly carved decoration, which is a highly original and distinctive interpretation of the Baroque (see figure 11.8). In spite of the modern tendency to view the style as a mark of the empire's decadence in the face of Western hegemony, the Ottoman Baroque sprang forth in the mid-115os/early 1740s, on the back of the peace treaties of 1152/1739. It was, in other words, a manner born under favorable conditions, and its blatant engagement with Western models takes on a pointed significance when considered in light of the Ottomans' recent success at Bel-

64 On the location, see Peker, Return of the sultan.

65 This account is known from a single manuscript copy that is now in the İstanbul Üniversitesi Nadir Eserler Kütüphanesi (MS. Türkçe Yazmalar 386). For an imperfect early twentieth-century print edition, see Ahmed Efendi, Tärīh. For a full transliteration and translation, see Ahmed Efendi, Ahmed Efendi's Tärīh. For an alternative transliteration, see Ahmed Efendi, Tarih. For analysis of the text, see Hochhut, Die Moschee Nûruosmâniye; Kuban, Tarih, imperfectly translated into English as Kuban, Notes; Rüstem, Ottoman Baroque 119-123, 132-133, 137-138, 147-148, 150-154.

66 Aḥmed Efendi, Ahmed Efendi's Tārīh 385-386, 447-448.

67 Rüstem, Ottoman Baroque 111-112.

68 Ibid. 120, 147-148. 


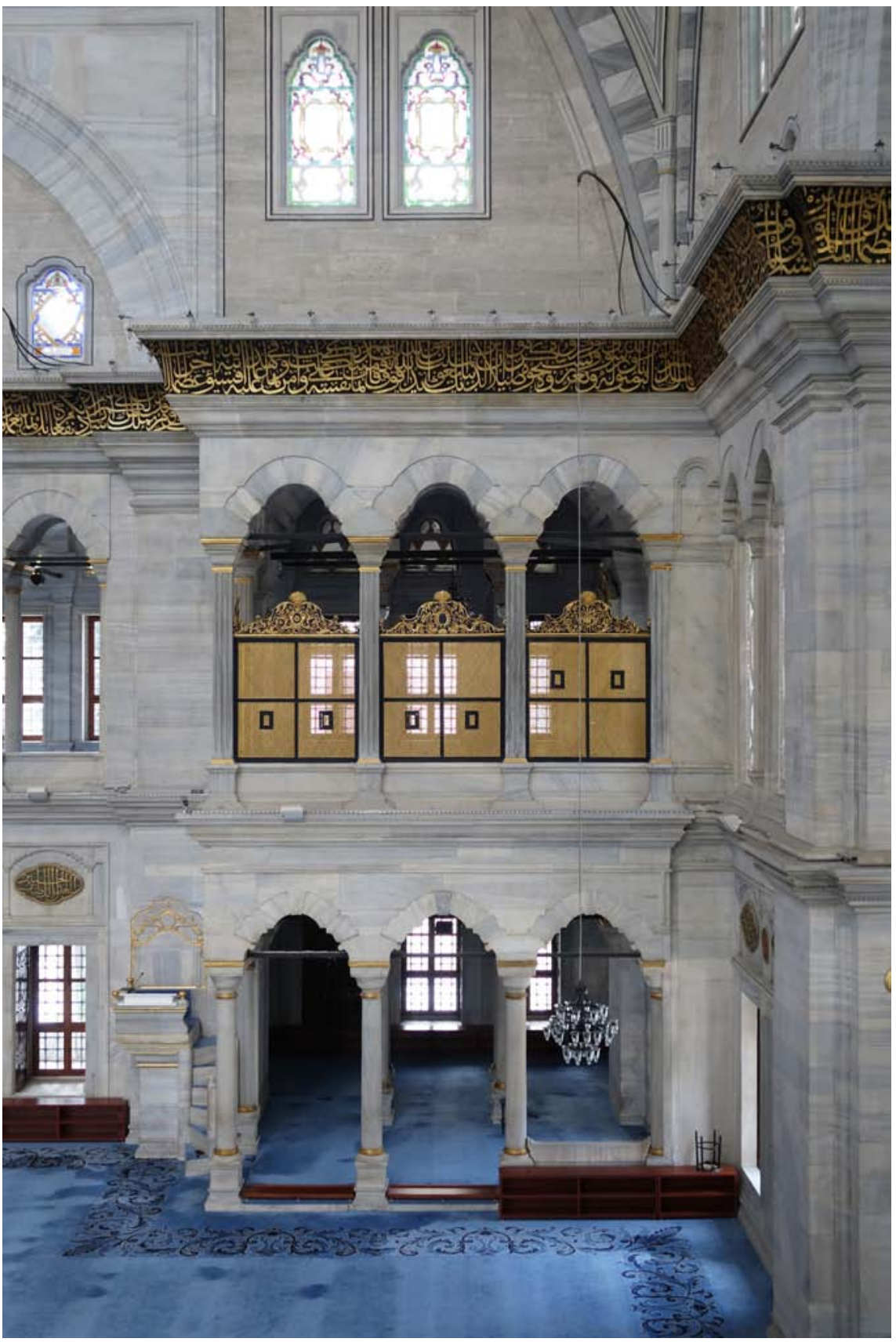

FIGURE 11.8 Nuruosmaniye Mosque, interior of the prayer hall looking toward the royal prayer loge

AUTHOR'S Рното 
grade, where the Habsburgs had left a number of new Baroque buildings. ${ }^{69}$ Foreign and local audiences were deeply impressed by the style, and numerous commentators of the time opined that the Nuruosmaniye - the first truly monumental deployment of the Ottoman Baroque - was the finest mosque in Istanbul. ${ }^{70}$ There is nothing in these assessments to indicate that the monument's innovative design was felt to compromise the seriousness of its function as an imperial mosque; on the contrary, the building's stylistic freshness made its meaning more current in the eyes of contemporary observers, for whom the more sober classical mode had lost appeal.

The Nuruosmaniye was not, however, a statement of $g \bar{a} z \bar{\imath}$ expansionism of the type propounded in earlier centuries. Enough time had passed since the downturn in Ottoman military fortunes that even the retaking of a former possession might now be presented as a significant conquest. Not everyone, to be sure, can have deemed it such: in a dour social commentary written in about 1153/1740, the moralistic Sufi Fażlızāde 'Alī dismisses the Treaty of Belgrade as a trifling gain that would ultimately fuel the empire's complacent descent into decline. ${ }^{71}$ Nevertheless, the view recorded by Peyssonnel shows that some, at least, were prepared to accept the revised threshold for victory. Another difference from the past was that this victory brought no new expectations of conquest: having secured peace with Christendom, the Ottomans were content to set themselves on a more diplomatic course with their traditional enemies and pursue a more amicable position in the European balance of power. Their appropriation of the Baroque was in part a reflection of this realignment, which also entailed a sustained effort to update the empire's institutions with selective reference to Western military and technological models. ${ }^{72}$

Self-assured though it was, then, the Nuruosmaniye celebrated the sultan less as a warrior on campaign—no sultan after Muștafā II (r. 1106-1115/16951703) personally led his troops ${ }^{73}$ - than as a magnanimous presence on home turf. This image is richly expressed by the mosque's royal pavilion, which is here more fully integrated into the overall ensemble (figure 11.9). While still clearly an ancillary to the prayer hall, the pavilion is now clad in stone like the rest

69 Rüstem, Ottoman Baroque, esp. 70, 92, 154-169. For other assessments of the Ottoman Baroque, see Kuban, Türk barok; Goodwin, A history of Ottoman architecture 380-419; Hamadeh, Ottoman expressions; Hamadeh, Westernization.

70 Rüstem, Ottoman Baroque 1, 154-157.

71 Kurz, Ways to heaven $28-3$ o.

72 For aspects of this wider context, see Ágoston, Military transformation; Aksan, Ottoman statesman, esp. 42-46; Berridge, Diplomatic integration; Eldem, 18. yüzyll, esp. 195-197; Naff, Ottoman diplomatic relations; Rüstem, Ottoman Baroque 164. 


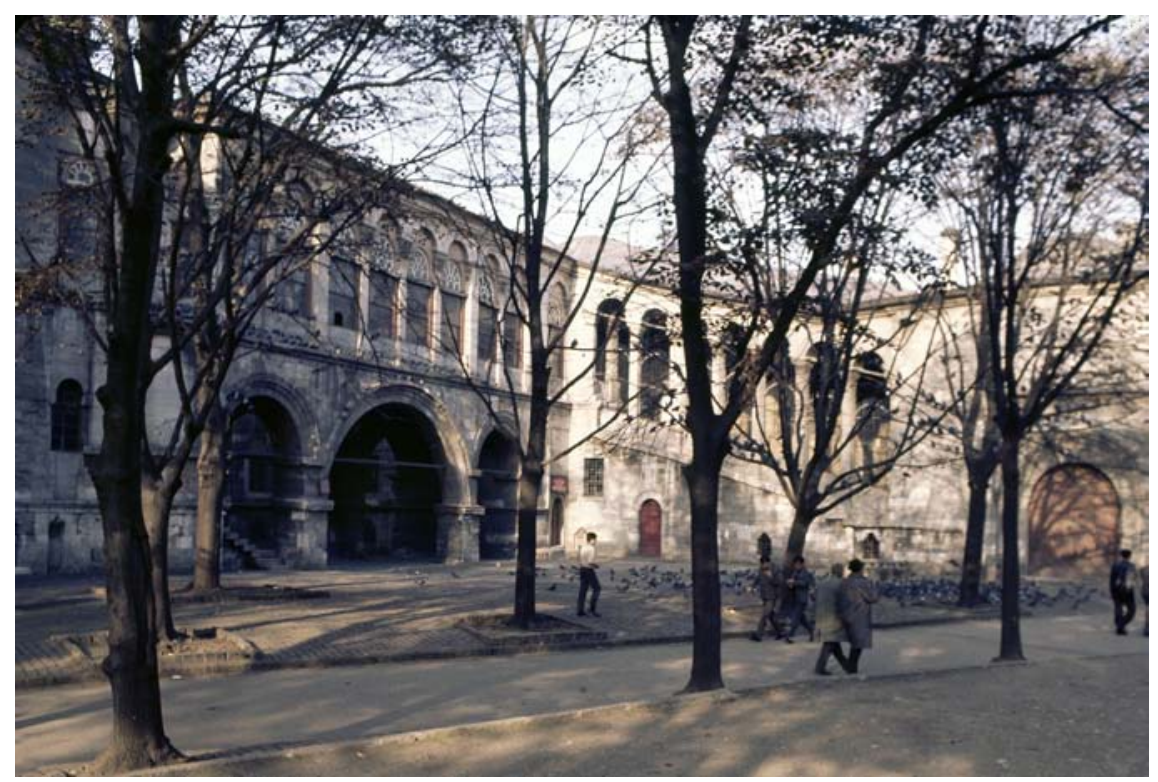

FIGURE 11.9 Nuruosmaniye Mosque, royal pavilion, with the attached prayer hall visible on the far left

PHOTO COURTESY OF WALTER B. DENNY

of the monument. It has, moreover, lost much of its residential appearance: the suite of rooms has been reduced to a single salon, with the majority of the pavilion composed of fenestrated arcades that form a grand ramp and elevated gallery leading to the sultan's prayer loge. The resultant L-shaped structure helps to delineate a secondary courtyard around the back and side of the mosque, where the gates into the complex are located. This open area set the stage for the sultan's visits, and what the pavilion had lost in its palatial air, it more than made up for by furnishing the Friday parade with a statelier culmination. ${ }^{74}$

Accounts of 'Osmān's inaugural visit to the mosque reveal how well the reconfigured pavilion complemented his ceremonial movements. Upon arriving at the precinct with a multitudinous cavalcade, 'Osmān dismounted his horse and, with a select entourage, entered the pavilion, whose generously sized arches rendered it a semiopen showcase for his passage. After a period of repose in the salon at the corner of the $\mathrm{L}$, 'Ossmān moved to the elevated gallery and watched as his grand vizier distributed robes of honor outside the ramp.

74 For the pavilion, see Rüstem, Ottoman Baroque 129-132. 
He then continued along the route into his loge within the mosque proper (figure 11.8). The highpoint of the ceremony came when the screens of the loge were momentarily opened to reveal the sultan to the congregation below, who prostrated themselves in salutation before proceeding to pray. ${ }^{75}$

What made the Nuruosmaniye's pavilion so effective was its ability not only to flaunt sultanic spectacle, but also to prolong its impact. With every stage of the ceremony made architecturally manifest, the pavilion stood as a perpetual reminder of such occasions, accruing in symbolism with each subsequent royal visit. The increasingly theatrical approach to framing and memorializing the sultan's presence during the twelfth/eighteenth century reflected a further rise in the importance of royal visibility. The sultan's movements were watched with ever more interest by his subjects, a growing number of whom were themselves engaging in such outdoor activities as picnicking and promenading. ${ }^{76}$ Whereas in previous centuries, the Friday parade was apt to be skipped every so often, nothing less than a weekly performance would now do, and any failure to undertake the procession caused real alarm. Public appetite to see the sultan could even have fatal results: after an outcry by his subjects, Mahmūd was forced to attend prayer while so gravely ill that he died riding back to the palace. ${ }^{77}$ It was also in this period that the sultan was expected to make moraleboosting appearances near the sites of great fires and other disasters. ${ }^{78}$ Far from betraying overcompensation for waning power, this heightened culture of display was a hallmark of Eurasian (early) modernity, tied to the burgeoning of public space, social and physical mobility, and leisure. ${ }^{79}$ The sultans took full advantage of these new opportunities for self-advertisement, presenting themselves ever more insistently to their subjects' eager gaze.

While martial prowess was no longer as important to the royal image in this postclassical climate, a sultan who ignored the criterion still risked censure. The Nuruosmaniye had engendered a conundrum: its construction revitalized a dormant practice that other sultans wished to capitalize on, but there were few new victories to justify further building work. 'Oșmān III's successor, Muștafā III (r. 1171-1187/1757-1774), was not to be put off, however. Having already built the small but stately Ayazma Mosque (1171-1174/1758-1761) in

\footnotetext{
75 Neftçi, Nuruosmaniye Camii açılış töreni; Rüstem, Ottoman Baroque 132-133.

76 Hamadeh, Public spaces; Hamadeh, The city's pleasures, 2008, 48-75, 110-138.

77 Rüstem, Ottoman Baroque 135.

78 The practice seems to have originated in the tenth/sixteenth century but did not become common until the twelfth/eighteenth. See Cezar, Osmanlı devrinde; Karateke, Opium 114115. Rüstem, Ottoman Baroque 134, 232.

79 For examples in other regions, see Duindam, Vienna and Versailles; Ledoux-Prouzeau, Les fêtes; Melo, Respect; Naquin and Rawski, Chinese society 83-9o; Tierney, Urban festival.
} 


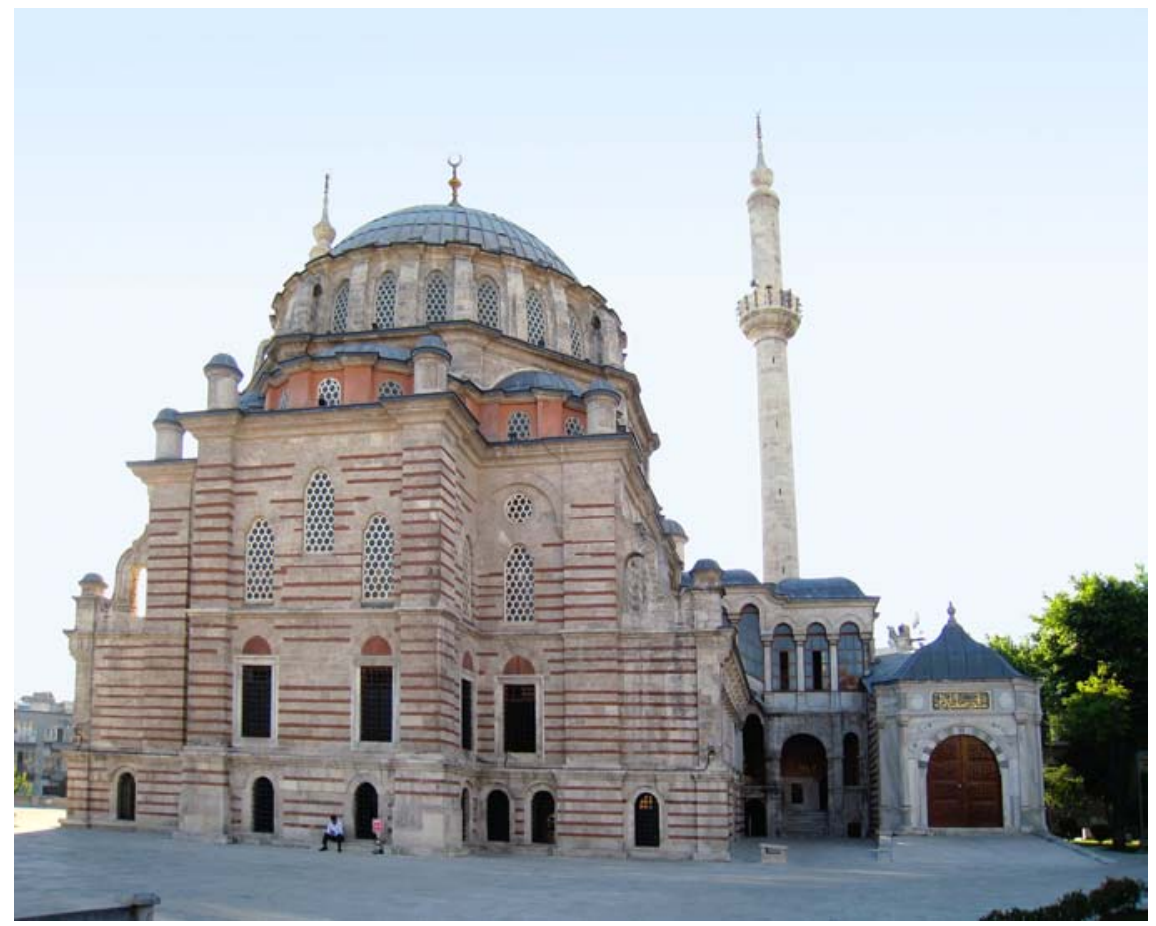

FIGURE 11.10 Laleli Mosque, Istanbul, 1174-1177/176o-1764, qibla façade of the prayer hall, with the royal pavilion on the right AUTHOR'S Рното

Üsküdar in memory of his mother and brother, ${ }^{80}$ the sultan embarked on his own foundation in the walled city, even as the empire was at peace. This mosque, the Laleli, was completed in 1177/1764, its largely Baroque form infused with prominent Byzantine references that make it one of the most distinctive of Istanbul's monuments (fig. 11.10). ${ }^{81}$ While its pavilion again takes the form of a dramatic ramped and arcaded passageway, the Laleli is smaller than the Nuruosmaniye and was originally built with a single minaret, ${ }^{82}$ perhaps to deflect the charge of unmerited extravagance. Muștafā was evidently aware of the issue, for after being reluctantly drawn into war with Russia in 1182/1768, he

8o For this mosque, see Bilge, Üsküdar Ayazma Camii; Goodwin, A history of Ottoman architecture, 387; Haskan, Yüzylllar boyunca Üsküdar i, 79-89; Kuban, Ottoman architecture, 543; Rüstem, Ottoman Baroque 172-182.

81 For this mosque, see Goodwin, A history of Ottoman architecture 388-391; Neftçi, Lâleli Külliyesi; Rüstem, Ottoman Baroque 182-198, 210-211; Tanyeli, Laleli Külliyesi.

82 Ayvansarāyī, The garden of the mosques 25 . 
seized upon the opportunity to claim gāzī status. He made known his desire for the title in Ramaḍān 1182/February 1769 and was granted it in Muharram/May following some early victories. Muștafâ's mosque could thus be retroactively legitimated, and it is telling that the second minaret-a royal prerogativewas added not long afterward. ${ }^{83}$

But the war did not go well for the empire, and when, in Shawwāl 1184/February 1771, Muștafā was hailed as a $g \bar{a} z \bar{\imath}$ while attending Friday prayers at the Hagia Sophia, two members of the congregation-a Mevlevi dervish and his Arab companion—shouted, "It is a lie! He is no gāzìl" (yalandır, gāzì değildir). The event was noteworthy enough that even the European press reported it. ${ }^{84}$ Only when reconstructing the mosque of Mehmed the Conqueror, which had been badly damaged in the earthquake of $1180 / 1766$, was Muștafā able to build without fear of criticism..$^{85} \mathrm{~A}$ stylistic throwback to the classical age, the new Fatih Mosque (1181-1185/1767-1771) is far grander than the Laleli, demonstrating that the latter, for all the questions it raised, was still conceived with traditional restrictions in mind. That the Laleli came to be known after its district rather than by the name of its founder may be another indication that Muștafā was understood to be skirting the rules and that a surer means of following in the Nuruosmaniye's footsteps had yet to be hit upon. ${ }^{86}$

\section{$3 \quad$ Hearts and Minds: The Beylerbeyi Mosque and the Rhetoric of Beneficence}

The Laleli was the last mosque to be built in the walled city by a sultan, ${ }^{87}$ though far from the last to be built in greater Istanbul. Utilizing the locational loophole, the rulers who came after Muștafā erected their foundations instead along the Bosphorus, and in so doing embraced a tactic that was both beyond reproach and more enduringly suited to the empire's new realities. The pattern was set by Mușțafā's half-brother and successor, 'Abdü'l-ḥamīd I (r. 11871203/1774-1789), whose reign was itself marked by momentous developments

83 Rüstem, Ottoman Baroque 182, 185. For the military background, see Aksan, Ottoman wars 149-151.

84 Göksu, Müellifi mechûl bir rûznâme 17; Hoey's Dublin Mercury, Intelligence.

85 For this mosque, see Goodwin, A history of Ottoman architecture 394-395; Kuban, Ottoman architecture 538-540; Rüstem, Ottoman Baroque 212-219.

86 Rüstem, Ottoman Baroque 182-183.

87 To be sure, royal patronage of mosques within the intramural city continued on a limited basis, though no new sultan's foundations were established: see Rüstem, Ottoman Baroque 288 n29. 
in Ottoman sultanic identity. 'Abdü'l-hamīd had inherited a beleaguered realm still at war with Russia, and though he quickly brought the conflict to an end in 1188/1774, the peace treaty signed at Küçük Kaynarca forced the empire to relinquish control of the Crimea, only for war to resume in 1201/1787 after Russia invaded the peninsula. ${ }^{88}$ The sultan's inability to present himself as a victor in battle was counterbalanced, however, by a more convincing claim to power: having already been recognized in the Treaty of Küçük Kaynarca as the religious leader of the Crimean Muslims, he was formally invested as caliph in $1204 / 1779 \cdot{ }^{89}$

The move to strengthen the Ottoman caliphate's legal framework continued a trend that can be traced back to the mid-eleventh/seventeenth century and that accelerated in the 113os-1140s/1720s, when the Ottoman ulamarebuffing the claims of the Afghan ruler Shah Ashraf Hotak (r. 1137-1142/17251729 , d. 1142/1730) to a localized caliphate-formulated new juridical arguments in favor of the sultan's unique position over all the world's Muslims..$^{90} \mathrm{~A}$ member of the Sunni Hotaki dynasty, which had wrested control of Iran from the Safavids in 1135/1722, Ashraf was in turn ousted in 1142/1729 by Nādir Afshār (r. 1148-116o/1736-1747), a military commander who restored the Safavids to power before putting himself on the throne in 1148/1736. (The Ottomans themselves had tried to grab a chunk of Iran in the wake of the Safavids' initial fall, though their gains were short lived.) The newly ascendant Nādir Shah, whose successors would rule Iran until 1210/1796, was eager to improve relations with the Ottomans by declaring Shi'ism a fifth school—the Ja'fari madhhab—of orthodox Islam, a step that entailed disallowing such provocative practices as the cursing of the first three "Rightly Guided" caliphs. ${ }^{91}$ Although Nādir's request for recognition of the Ja'fari school was ultimately rejected by the Ottomans, and war between the two states would continue intermittently into the thirteenth/nineteenth century, the fall of the Safavids had, by the $1140 \mathrm{O} / 173$ os, essentially removed the specter of Shi' ism both as a practical threat and as an ideological foil, and some degree of rapprochement between Iran and

88 Aksan, Ottoman wars 157-170.

89 On the significance of the caliphate to 'Abdü'l-hamìd, see Sarıcaoğlu, Kendi kaleminden 211-225. The investiture is briefly recorded with the words "Investiture Califale: enfin consomée" in a summary of a French diplomatic dispatch dated 3 December 1779. I was not able to find the letter summarized by this entry, nor any further information on this event. See Centre des archives diplomatiques de Nantes, 166Po/A/55, $227 \mathrm{~b}$.

90 Akbulut, The scramble 135-159; Tucker, Peace negotiations 20-22. For the eleventh/seventeenth-century background to this development, see Emecen, Hilâfetin devri 562; and the chapter by Selim Güngörürler in the present volume.

Tucker, Nadir Shah; Tucker, Peace negotiations, esp. 25-32. 
the Ottomans ensued. ${ }^{92}$ This new relationship, which built on earlier attempts at ecumenical dialogue with the Safavids that are analyzed by Selim Güngörürler in the present volume, meant that confessionalization as defined with reference to a Shi'i other was no longer an especially relevant concern for the Ottomans. In these altered circumstances, a different mode of Sunnitizationone designed to augment the sultan's religious and social leadership-came increasingly to the fore.

As Madeline Zilfi has discussed, both Muștafā and 'Abdü'l-ḥamīd formalized existing notions of the sultan as "scholar-master" by establishing the custom of the hużür-ı hümāyūn dersleri (Imperial Command Lectures) held at the palace during Ramadan. These annual events, which began in 1172/1759 and continued until 1340/1922, involved multiple sessions attended by various members of the ulama, who would gather in the sultan's presence as lecturers and respondents to debate the Quranic commentary of the medieval Hanafi jurist 'Abdallāh ibn 'Umar al-Bayḍāwī (d. 691/1291?). ${ }^{93}$ Besides being staged for the benefit of a courtly audience, including female spectators screened off by curtains, the lectures had a public dimension: each was preceded by a grand cavalcade that broadcast the sultan's diligence in mingling with and nourishing his empire's clerics, whose status had more generally risen over the course of the twelfth/eighteenth century. ${ }^{94}$ Concurrent with—and related to-Muștafā and 'Abdü'l-hamīd's sponsorship of the lectures was a tightening of social regulations, aimed in particular at curbing the perceived transgressions of women and non-Muslims. ${ }^{95}$ Two sides of the same coin, the spiritual fervor and moralistic agenda of these years belonged to what Zilfi has characterized as a series of "calculated responses" by which the sultans addressed "the gradual transformation of an authority derived from war to an authority based on social stability." 96

These multipronged responses - already operative by the middle decades of the twelfth/eighteenth century — paved the way for the more overt invoca-

92 Özervarl, Between tension and rapprochement; Tucker, The peace negotiations, esp. 3336.

93 Zilfi, A medrese. On the longer history of the Ottoman sultans as patrons of Hanafi doctrine and overseers of piety, see Burak, The second formation; and the chapter by Evren Sünnetçioğlu in the present volume.

94 Zilfi, A medrese 188 . On the rising status of the ulama, see Zilfi, The politics of piety $43^{-80}$, 183-235.

95 Zilfi, A medrese 189. For such regulation more generally in the twelfth/eighteenth-century Ottoman context, see Başaran, Selim III; Tuğ, Politics of honor; Zarinebaf, Crime 125-140; Zilfi, Women 45-95.

96 Zilfi, A medrese 190-191. 
tions of religious stewardship that would follow Küçük Kaynarca. The resultant boost to the Ottoman caliphate's significance was felt both within and without the empire, ${ }^{97}$ and it was also in these years that the legend arose concerning the Abbasids' supposed transfer of caliphal power to the Ottomans after the conquest of Mamluk Egypt. ${ }^{98}$ Such elaborations of the sultan's spiritual role further bolstered the idea that his ability to serve Islam was not contingent on his conquering foreign territories or defeating "infidel" foes. Through good works, unstinting care for his subjects, and the protection of his existing dominions - which included the holy cities of Mecca and Medina-the sultan might continue to assert himself as an influential agent of the divine will. ${ }^{99}$

The concept of sultanic superintendence found a fitting vehicle in the recently reenergized category of religious architecture, as 'Abdü'l-hamīd demonstrated with two major projects that he undertook in tandem with each other: the Beylerbeyi Mosque, built on the Asian shore between 1191/1777 and 1192/ $1778,{ }^{100}$ and the Hamidiye, a mosque-less complex constructed in the vicinity of the Yeni Cami between 1189/1775 and 1194/1780.101 The inception of the latter undertaking is recounted by the court chronicler Enverī, who tells us that the sultan wished to "build an exalted mosque and lustrous imarret [public soup kitchen ${ }^{102}$ ] for the sake of God Almighty in his sublime caliphal seat, and so he immediately expressed his kingly resolve to realize this good work. But most of the selected places already had mosques and masjids, and it came to his pure mind that the noble mosque of Her Majesty the late Vālide Sulțān —may she rest in peace-was in need of an 'imäret." ${ }^{103}$ Delicately sidestepping the

97 Arnold, The caliphate 163-183; Deringil, The well-protected domains 46-50; Karpat, The politicization 68-89.

98 Arnold, The caliphate 142-147; Deringil, The well-protected domains 46-47.

99 On the role of such religiosity in legitimating the Ottomans sultans, see Crane, The Ottoman sultan's mosques 193-201; Karateke, Opium.

100 For the Beylerbeyi Mosque, see Baraz, Teşrifat meraklısı i, 110-118; Batur, Beylerbeyi Camii; Goodwin, A history of Ottoman architecture 397-399; Rüstem, Ottoman Baroque 23425 o.

101 For the Hamidiye complex, see Alpay, I. Sultan Abdülhamid Külliyesi; Bülbül, IV. Vakıf Han'ın; Cunbur, I. Abdülhamid vakfiyesi; Eyice, Hamidiye Külliyesi; Rüstem, Ottoman Baroque 222-234.

102 This definition of 'imāret became standard in the early modern period and displaced the word's earlier use as a term for the distinctive multifuctional T-type buildings (later converted into mosques) that are characteristic of early Ottoman architecture. See the chapter by Çiğdem Kafescioğlu in the present volume.

103 "Öteden-berü Halîfe-i kerāmet-āșār ve Hākān-ı ma'delet-kār ḥażretleriniñ țab-ı hümāyūn-ı

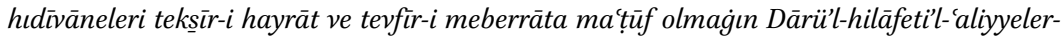




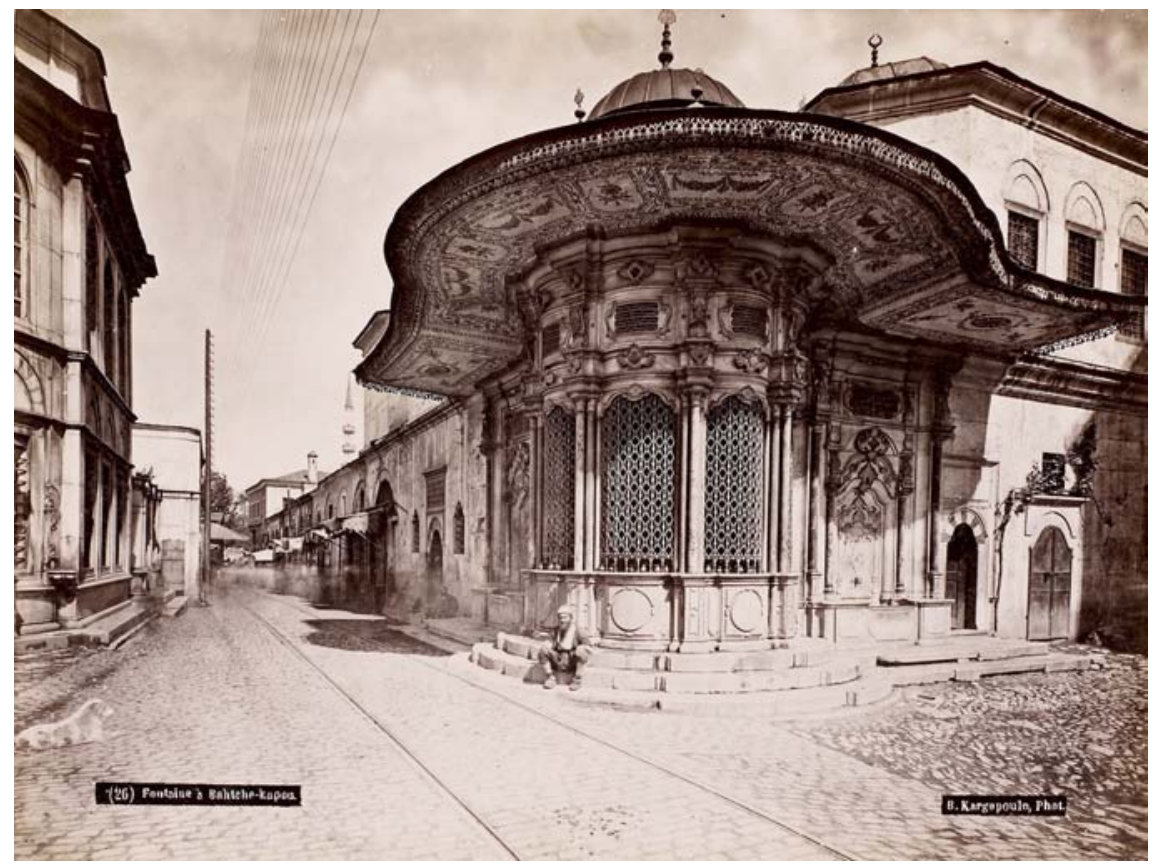

FIGURE 11.11 Hamidiye Complex, Istanbul, 1189-1194/1775-1780, with the sebil in the right center and the tomb partially visible on the far left. Albumen print by Basil Kargopoulo, 1875

GETTY RESEARCH INSTITUTE, LOS ANGELES. PIERRE DE GIGORD COLLECTION [96.R.14 (A11.V2.F12B)]

obstacles that 'Abdü'l-hamīd would have faced had he attempted a more ambitious intramural scheme, this account emphasizes his pious purpose in enlarging the preexisting Yeni Cami complex. What he created was nonetheless a substantial complex in its own right, comprising not only a soup kitchen, but also a madrasa, library, primary school, sebill (fountain kiosk), and his own eventual tomb (figure 11.11). (The soup kitchen and primary school are no longer extant, while the sebil has been relocated.) Rather than being walled off, the buildings making up the complex hugged the busy street that passed through it and — through its exuberant Baroque stonework—appealed directly to the

inde li-vechi'llāhi te'ālā bu eșnāda bir cāmi'-i mu'allā ile bir 'imāret-i zïbende binā țarh $u$ inşā olunması żamīr-i münīr-i şehriyānelerine ilhām ve der'aḳab ol kār-ı hayriñ ḳuvveden fìle getirilmesin 'uhde-i mülūkānelerine iltizām buyurup lākin ihtiyār olunacaḳ mahalleriñ ekșeri cevāmi' ü mesācidden 'ibāret ve cennetmekān Vālide Sulțān—țābete șerāhā-

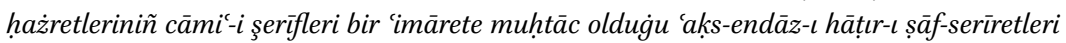
olmag̀la." Enverī, Tārīh 477b. 


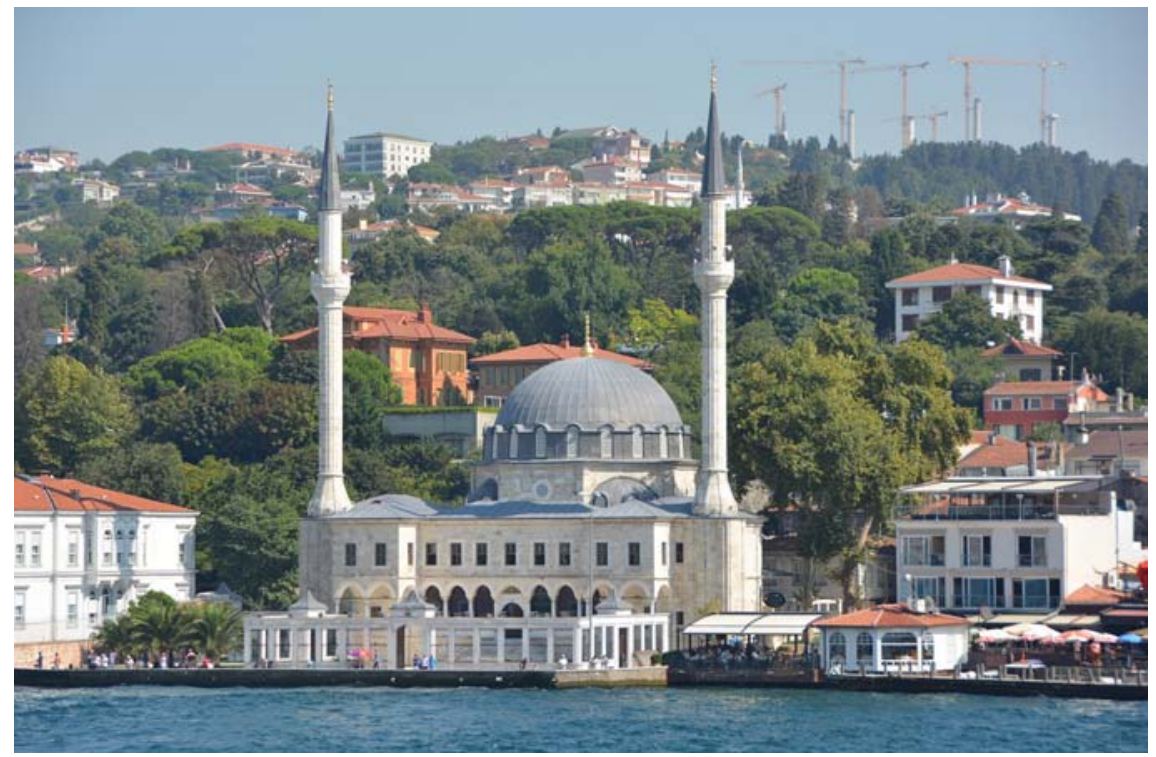

FIGURE 11.12 Beylerbeyi Mosque, Beylerbeyi, Istanbul, 1191-1192/1777-1778, renovated 12351236/1820-1821

PHOTO COURTESY OF ANDY TEACH

people, generously serving them while emphatically identifying their benefactor, whose domed tomb was the stateliest element of the ensemble.

While 'Abdü'l-hamīd refrained from incorporating a mosque into the Hamidiye Complex, the rather distant Beylerbeyi was from the outset understood as a related and complementary enterprise, with contemporary sources discussing them together (figure 11.12). ${ }^{104}$ The sultan could make a virtue of the mosque's decorous location, which affirmed the reach of his patronage by linking both continents of the city together. Like the Hamidiye, the Beylerbeyi is architecturally extroverted, its otherwise humble form enlivened by an eye-catchingly novel frontispiece: the royal pavilion, which, instead of being a dependency attached to the corner, has here been fused with the prayer hall's entrance porch, replacing the courtyard and giving the mosque an entirely original kind of façade. ${ }^{105}$ This reconfiguration was probably a result of the mosque's placement on the Asian shore, which left its entrance facing the water. The unknown architect (traditionally held to be Meḥmed Țāhir Agha

104 Ayvansarāyī, The garden of the mosques 480-486; Cunbur, I. Abdülhamid vakfiyesi 37; Enverī, Tärīh, 569a.

105 Kuran, The evolution of the sultan's pavilion 282. 


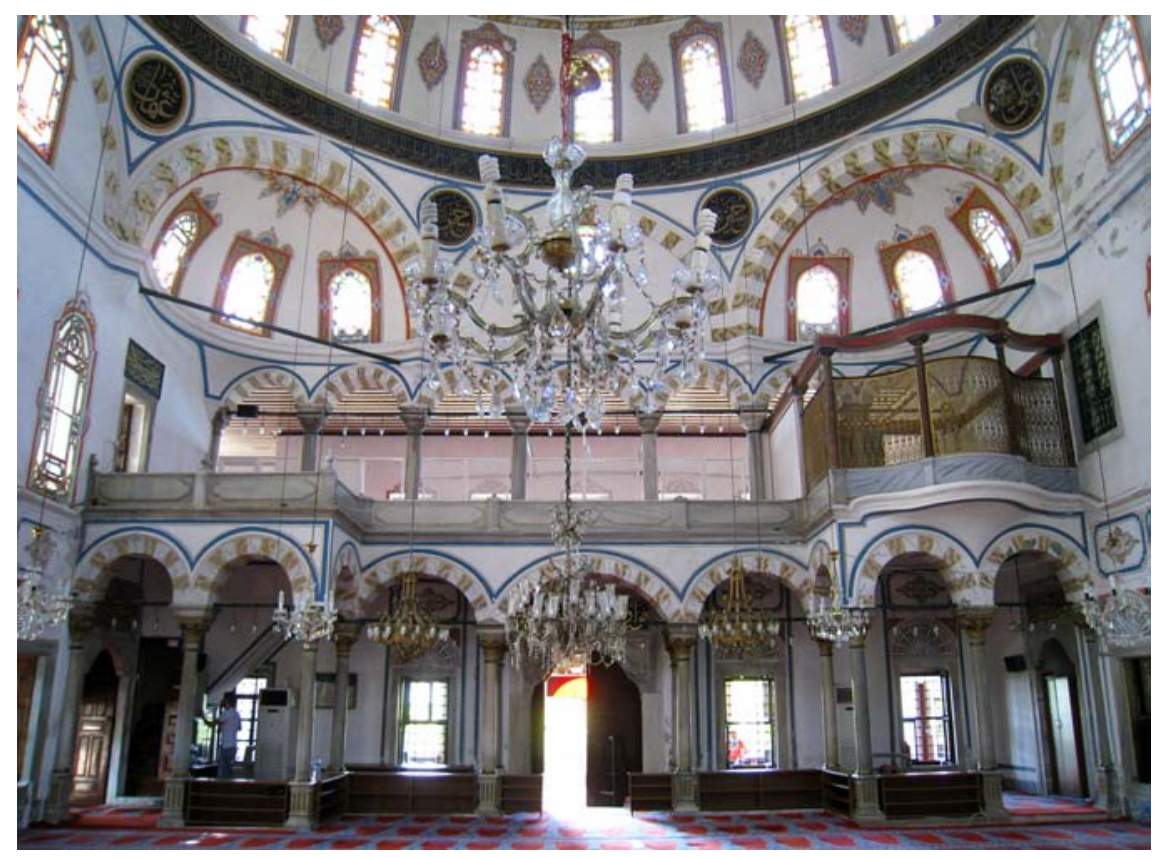

FIGURE 11.13 Beylerbeyi Mosque, interior looking toward the entrance, with the royal prayer loge on the right

AUTHOR'S Pното

(d. after 1202/1788)) took advantage of this topographical good fortune to build a mosque that could evoke a waterfront palace, thereby returning the pavilion to its formerly residential character. Inside, the scheme entailed moving the lattice-screened royal loge from its usual position near the qibla wall to the back of the prayer hall, so that the sultan now overlooked the congregation below (figure 11.13). Conceptually collapsing the distance between ruler and ruled, this fusion of palace and mosque recalls the spatial arrangement of the Imperial Divan, where any Ottoman subject could seek justice from the sultan's representatives under a grilled window from which the sovereign himself might be watching. ${ }^{106}$

106 A domed structure located in the second court of the Topkapı Palace, the Imperial Council (Dīvān-ı Hümāyūn) was constructed in the tenth/sixteenth century and redecorated in the Baroque style in 1207/1792, see Necipoğlu, Architecture, ceremonial, and power $5^{8-}$ 61; Rüstem, Ottoman Baroque 243-244, 261-262. Başaran and Başak Tuğ argue that the Imperial Council was no longer used for the hearing of petitions by the twelfth/eighteenth century, when the grand vizier held his own assemblies at the Sublime Porte. The sources, however, reveal that the council continued to convene at the Divan and hear petitioners' 


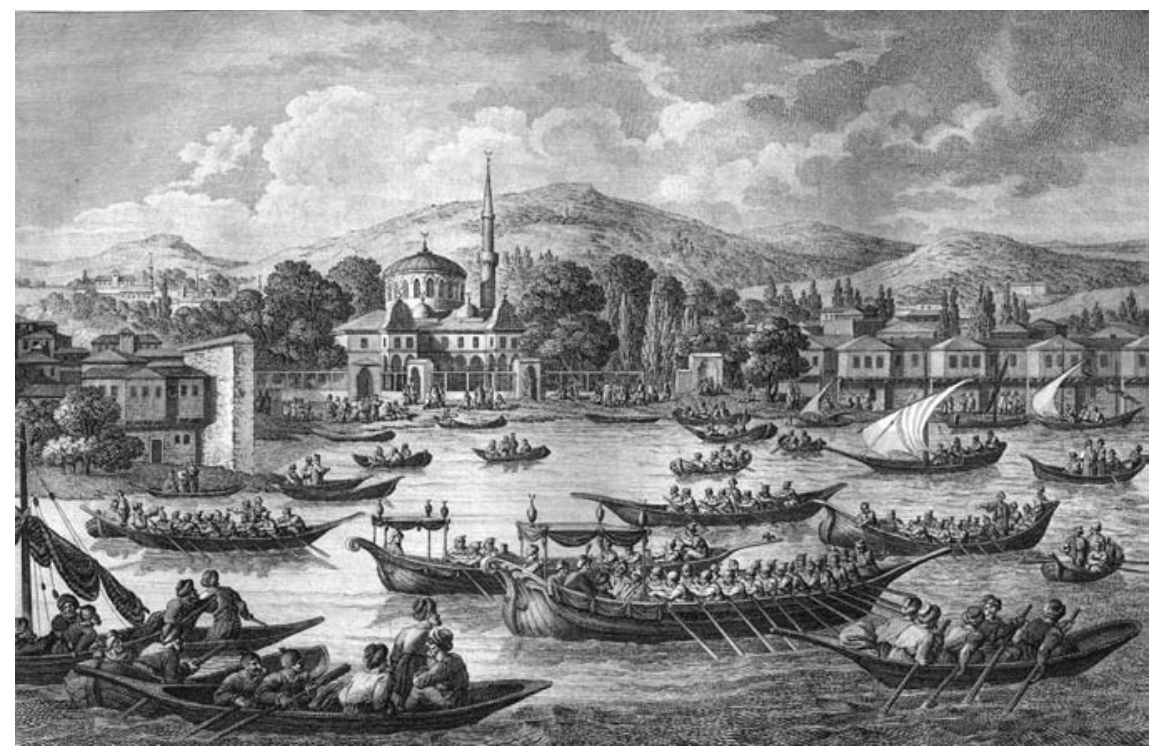

FIGURE 11.14 View of the Beylerbeyi Mosque from the Bosphorus during a visit by Mahmūd II, showing the original single minaret. By Wolf after Ludwig Fuhrmann, from Edward Raczyński, Dziennik podróży do Turcyi odbytey w roku MDcccXIV (Wrocław, 1821), pl. 44. Engraving on paper COURTESY OF THE OSSOLIŃSKI NATIONAL INSTITUTE, WROCŁAW [13.737]

Although seemingly an ad hoc experiment inspired by a particular setting, the Beylerbeyi's arrangement proved a far-reaching success, establishing a new paradigm that almost all subsequent imperial mosques would follow. Its popularity is not difficult to explain. The foregrounding of the pavilion yielded an aesthetically and symbolically cohesive design that proclaimed the mosque's royal status without the expense of a courtyard, even in the absence of monumental scale. As we can see from an engraving of Beylerbeyi during a visit by 'Abdü'l-ḥamīd's son Mahmūd II (r. 1223-1255/18o8-1839) in 1229/1814, the pavilion frontage also served as an impressive backdrop to processions by water, which the sultans were undertaking with growing frequency when attending Friday prayers (figure 11.14). ${ }^{107}$ This same image shows the mosque with its origi-

complaints on a regular, if less frequent, basis. Başaran, Selim III 184-185; Tuğ, Politics of honor 75-78; Mouradgea d' Ohsson, Tableau général vii, 213-220; Watkins, Travels ii, 224, 226 (this corrects an erroneous reference in my book); Pertusier, Promenades ii, 277-278.

107 The engraving, made after a drawing by the artist Ludwig Fuhrmann, appears together with another scene of the visit in Raczyński, Dziennik podróży, plates 43-44, reproduced and discussed in Rüstem, Ottoman Baroque 245-247. 
nally single minaret; the two that stand today were added in between $1235 / 1820$ and 1236/1820-1821 by Mahmūd, who enhanced the building to reflect the unanticipated prestige it had come to enjoy.

The creation and impact of the Beylerbeyi were embedded in a larger phenomenon of shoreline development that had begun with the court's return to Istanbul in 1115/1703. In a process analyzed by Tülay Artan and Shirine Hamadeh, the Bosphorus was transformed during the twelfth/eighteenth century into a ceremonial thoroughfare dotted with sultanic and elite residences. ${ }^{108}$ The addition of the mansion-like Beylerbeyi to this avenue consolidated the royal presence in explicitly religious terms, and this model was perpetuated well into the thirteenth/nineteenth century by a series of mosques that, as well as emulating the Beylerbeyi's plan, were likewise located along or close to the water. ${ }^{109}$ The wholesale shifting of imperial mosque patronage to the shoreline suburbs represented a notable break from earlier norms, and one that was a wise move in several regards. Besides providing an elegant solution to the rule described by Peyssonnel, the suburbs offered the sultans fertile new ground to extend their largesse beyond the crowded walled city by building up the areas around their mosques, which typically came with public drinking fountains and in some cases more extensive dependencies.

The potential of this approach was fully recognized by 'Abdü'l-hamīd's nephew and successor, the reformist Selīm III (r. 1203-1222/1789-18o7, d. 1223/ 1808), whose self-named Selimiye Mosque in Üsküdar was the centerpiece of an entire new neighborhood complete with gridded streets, shops, and factories (figure 11.15). ${ }^{110}$ Erected between 1216/1802 and 1220/1805, the hilltop mosque was a careful fusion of earlier Ottoman Baroque experiments, combining the Beylerbeyi's pavilion-fronted arrangement with the elegance and loftiness of the Nuruosmaniye. Among the other buildings of Selīm's new district were barracks for his famous Nizāam-ı Cedīd (New Order) army—a modern infantry trained on Western models ${ }^{111}$ — and a dervish lodge for the Naqsh-

108 Artan, Architecture as a theatre of life; Artan, Istanbul 305-308; Hamadeh, The city's pleasures $17-47$.

109 For a survey of these mosques, see Berberoğlu, Boğazın incileri. For their architecture, see Wharton, The architects.

110 For the mosque and its district, see Batur, Selimiye Camii; Goodwin, A history of Ottoman architecture 413; Kuban, Ottoman architecture 545; Rüstem, Ottoman Baroque 256-265. For the Selimiye's formal and symbolic impact on Mahmūd II's Nusretiye Mosque (12381241/1823-1826), see Rüstem, Victory, esp. 101-102.

111 For the barracks, see Batur, Selimiye Kışlasi; Kuban, Ottoman architecture 555. For the political and military background, see Aksan, Ottoman wars 180-258; Finkel, Osman's dream, 389-422; Shaw, Between old and new; Yaycioglu, Partners 38-63. 


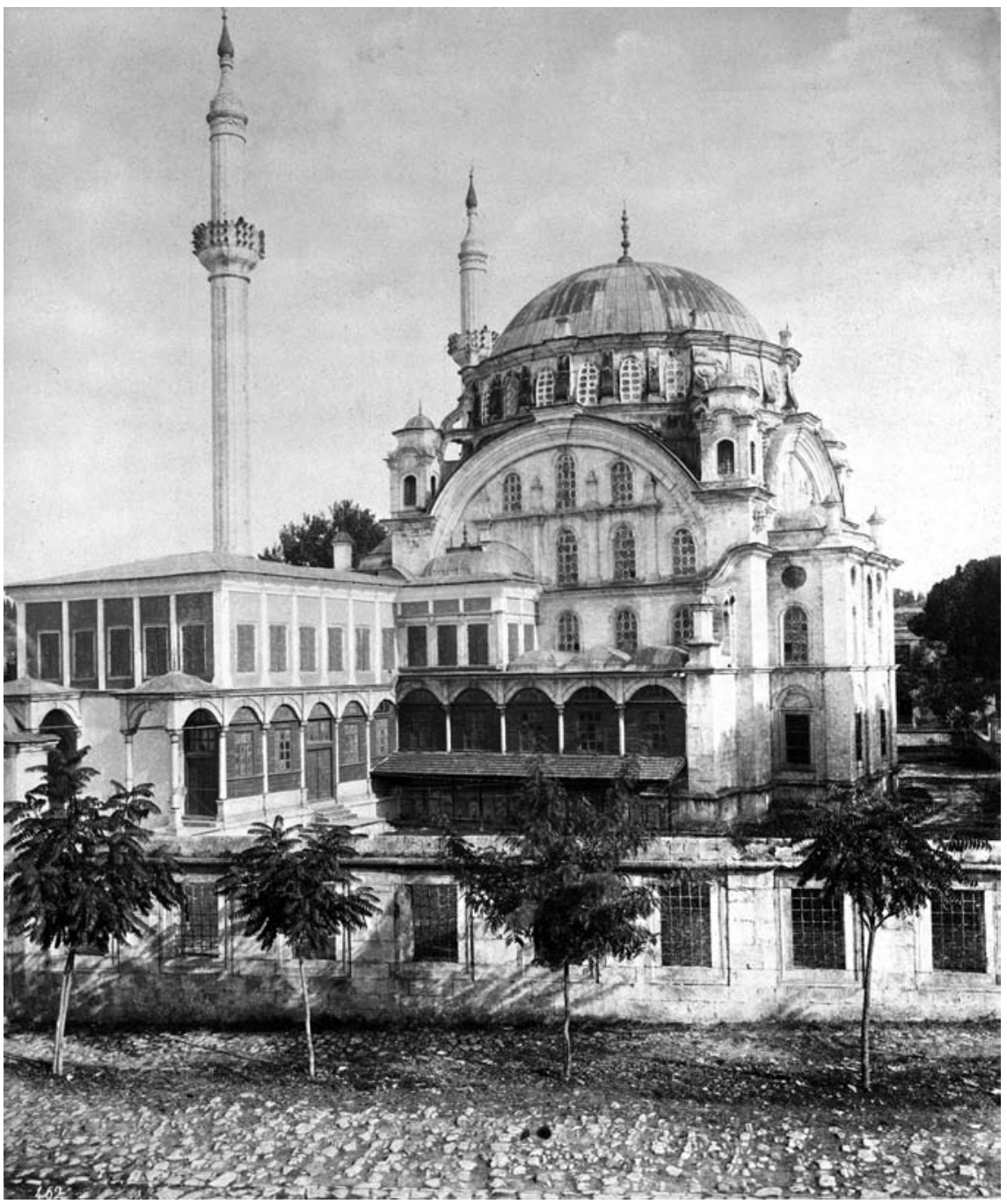

FIGURE 11.15 Selimiye Mosque, Üsküdar, Istanbul, 1216-1220/1802-1805, view toward the mosque's right side, with the royal pavilion projecting toward the foreground (the original minaret caps were conical). Albumen print by Abdullah frères, 1880-1893

LIBRARY OF CONGRESS, WASHINGTON, D.C. PRINTS AND PHOTOGRAPHS DIVISION, ABDUL HAMID II COLLECTION [LC-USZ62-81873] 
bandi order, who, together with the Mevlevi, were enthusiastic advocates of Selīm's reforms. ${ }^{112}$ The support that Selim enjoyed from these unimpeachably orthodox Sufi groups shows once again how central Sunnism remained to the Ottoman royal brand in this late period, even if certain quarters of the ulama joined with the janissaries in opposing the New Order. ${ }^{113}$ As if to accentuate the message, the Selimiye's Naqshbandi lodge was built opposite the famous shrine of the eighth/fourteenth-century saint Karaca Ahmed, who was venerated by the janissary-affiliated Bektashi order. The confrontational juxtaposition of state-backed (and state-backing) orthodox Sufis and their questionable "heterodox" rivals emblematized the Selimiye's commitment to righteous modernization. ${ }^{114}$ Clearly visible from across the Bosphorous, this striking new socioreligious complex announced to the wider city that Selim's reforms were being undertaken for the well-being of the state, and hence of Islam itself.

The Selimiye's visual and topographical impact points to another reason behind the growing preference for such suburban patronage. Away from the massive landmarks and dense fabric of the walled city, the later mosques faced less competition and could continue to impress despite being smaller than their intramural forerunners. Revised traditions of architectural decorum further secured the mosques' legibility as imperial works: the recently introduced pavilion façade entrenched itself as an unmistakable sultanic marker, and even the use of a domed prayer hall-previously commonplace in nonroyal commissions - became rare at other levels of patronage after the midtwelfth/eighteenth century, at least as far as Istanbul was concerned. And so while numerous servants of the state and other well-to-do individuals joined the ruler in erecting new mosques in the expanding capital, their contributions generally made use of hipped roofs that posed no real challenge to their domed sultanic counterparts, which thus rose as beacons of kingly munificence along the city's mushrooming shoreline suburbs. ${ }^{115}$ The reduced scale of these later sultanic mosques might even bolster their credibility as symbols of the gener-

112 For the lodge, which was rebuilt between $1250 / 1834$ and 1251/1835-1836 and is today known as the Küçük Selimiye Çiçekçi Mosque, see Haskan, Yüzyıllar boyunca Üsküdar i, 142-157; Tanman, Selimiye Tekkesi. For Selīm's Sufi backers, see Heyd, The Ottoman 'ulemā, esp. 33; Weismann, Naqshbandiyya 77-78; Yaycioglu, Janissaires; Yaycioglu, Partners 50, 58-61.

113 Heyd, The Ottoman 'ulemā 33.

114 For Karaca Aḥmed's shrine, which is part of an eponymous cemetery, see İşli, Karacaahmet Mezarlığı. On the reformists' hostility toward the janissaries and Bektashis, see Heyd, The Ottoman 'ulemā 41-42. On the role of the Sufis in backing the Ottoman sultanate (and caliphate) in earlier periods, see Yılmaz, Caliphate.

115 Rüstem, Ottoman Baroque 293nı. For Istanbul's thirteenth/nineteenth-century expansion, see Çelik, The remaking. 


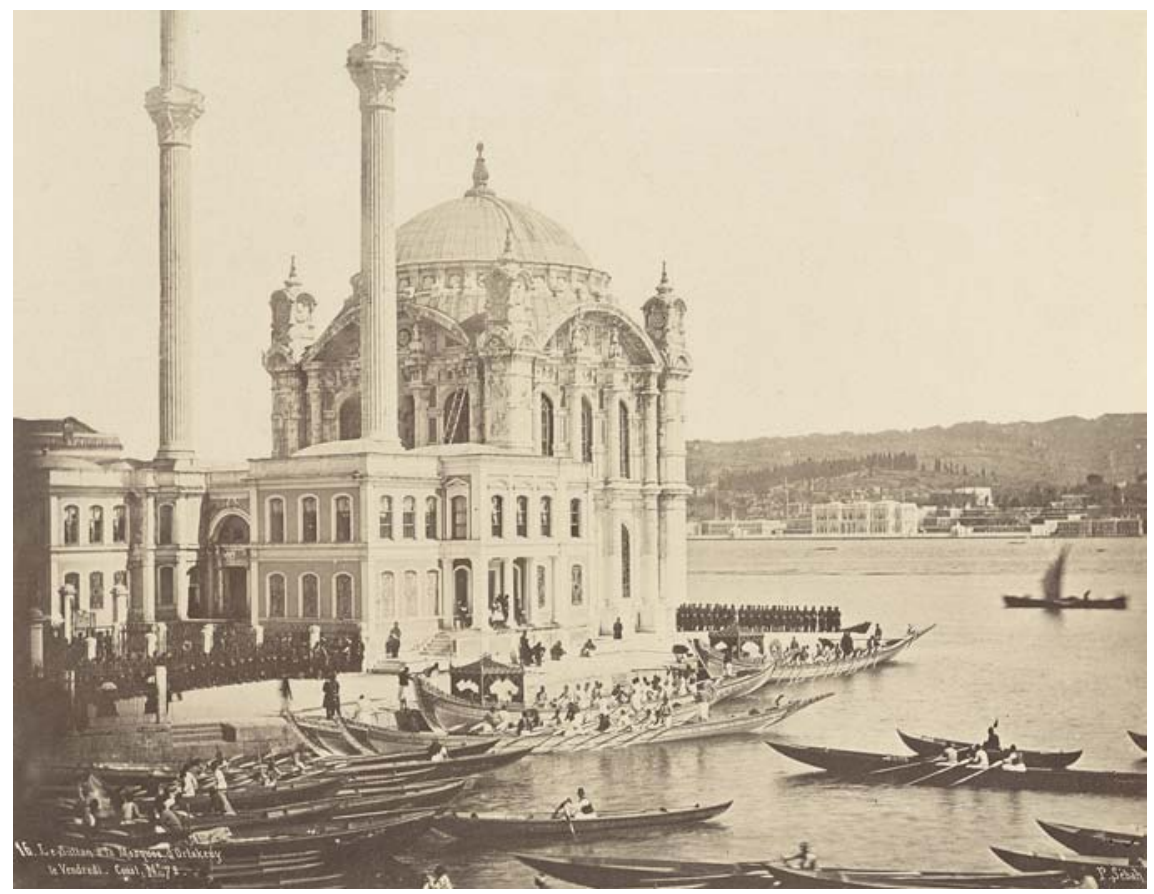

FIGURE 11.16 Ortaköy Mosque (Büyük Mecidiye Mosque), Ortaköy, Istanbul, completed 1271/1854, view of a royal visit for the Friday prayer. Photographed by Pascal Sébah, 1885. Albumen print GETTY RESEARCH institute, LOS ANGELES. PIERRE DE Gigord COLLECTION [96.R.14 (A9.F24B)]

ous but commanding hold of their founders: with the prayer hall diminished in size as the pavilion acquired greater prominence, these spaces assumed the nature of royal chapels where worshippers were permitted the honor of praying under the sovereign's auspices. ${ }^{116}$

The conceit of sultanic attentiveness was underscored by the lavish visits that regularly enlivened these monuments, which constituted new destinations in an already busy ceremonial roster (figure 11.16). Crisscrossing the waterways, the multiplied processional routes associated with this building activity formed a citywide network that spoke of the sultan's comprehensive and beneficent dominance, an idea physically substantiated by the mosques themselves. Indeed, more than any other kind of Ottoman imperial foundation, the post-

116 The comparison to chapels is made (although framed almost as a deficiency) also in Crane, The Ottoman sultan's mosque 190, 193, 205. 
Beylerbeyi model treats the royal presence as a precondition of its design: the pavilion stands front and center always ready to receive the sultan, forever concretizing his position among-and over-his subjects. It is their promise of perpetual access to the ruler that renders the later mosques such effective encapsulations of the state's religiopolitical ideology. Wielding the concept of royal piety in terms that built on Ahmed I's daring experiment, the imperial mosque in its final form absolved the sultan from the obligations of a holy warrior. To serve the Sublime State as God's chosen representative was, these monuments declared, victory enough.

\section{Acknowledgments}

I wish to thank Tijana Krstić and Derin Terzioğlu for inviting me to participate in the workshop out of which this article grew. They and the anonymous reviewer offered extremely helpful feedback on earlier drafts.

\section{Bibliography}

\section{Primary Sources}

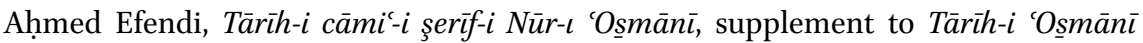
encümeni mecmüass, Istanbul 1335/1337/1919. (Reprinted in Hocchut, Moschee Nûruosmâniye, 158-208.)

Aḥmed Efendi, Tarih-i câmi-i Nuruosmânî, ed. A. Öngül, in Vakıflar dergisi 24 (1994), 127-146.

Aḥmed Efendi, Ahmed Efendi's Tärīh-i cāmi'-işerîf-iNūr-ı 'Oșmānī (History of the noble Mosque of Nuruosmaniye), 1756-1757, trans. and ed. Ü. Rüstem, in Architecture for a new age: Imperial Ottoman mosques in eighteenth-century Istanbul, PhD diss., Harvard University 2013, 381-512.

'Ālī, M., Counsel for sultans of 1581: Edition, translation, notes, trans. and ed. A. Tietze, 2 vols., Vienna 1979-1982.

Ayvansarāyī Hüseyin Efendi (enlarged by 'Alī Ṣațı Efendi), The garden of the mosques: Hafiz Hüseyin al-Ayvansarayı’s guide to the Muslim monuments of Ottoman Istanbul, trans. and ed. H. Crane, Leiden, Boston and Cologne 2000.

Ca'fer Efendi, Risāle-i mi'māriyye: An early-seventeenth-century Ottoman treatise on architecture, trans. and ed. H. Crane, Leiden and New York 1987.

Enverī, S., Tärīh-i Enverī, Süleymaniye Kütüphanesi, Ms Yahya Tevfik 253.

Evliyâ Çelebi, Evliyâ Çelebi seyahatnâmesi: Topkapı Sarayı Bağdat 304 yazmasının transkripsiyonu, 10 vols., ed. O.Ş. Gökyay et al., Istanbul 1996-2007. 
Göksu, S. (ed.), Müellifi mechûl bir rûznâme: Osmanlı-Rus harbi esnâsında bir şahidin kaleminden İstanbul (1769-1774), Istanbul 2007.

Gontaut-Biron, J. de, Ambassade en Turquie de Jean de Gontaut Biron, baron de Salignac, ${ }_{1605}$ à 1610, 2 vols., ed. Théodore de Gontaut Biron, Paris 1888-1889.

Grelot, G.-J., A late voyage to Constantinople [...], trans. J. Phillips, London 1683 .

Hoey's Dublin Mercury, Foreign intelligence, April 11-13, 1771, issue 698.

Mouradgea d'Ohsson, I., Tableau général de l'Empire Othoman, divisé en deux parties, dont l'une comprend la législation mahométane; l'autre, l'histoire de l'Empire Othoman, 7 vols., Paris 1788-1824.

Pertusier, C., Promenades pittoresques dans Constantinople et sur les rives du Bosphore, suivies d'une notice sur la Dalmatie, 3 vols., 1815 .

Peyssonnel, C.-C. de, Strictures and remarks on the preceding memoirs, in François, baron de Tott, Memoirs of baron de Tott. Containing the state of the Turkish empire and the Crimea [...], English trans., 2 vols., London $1785,{ }^{2} 1786$ (2nd ed.), i, part 4, 161-287.

Raczyński, E., Dziennik podróży do Turcyi odbytey w roku MDcccXIV, Wrocław 1821.

Râşid, M. and Çelebizâde İsmaîl Âṣım Efendi, Târih-i Râşid ve zeyli, 3 vols., ed. A. Özcan et al., Istanbul 2013.

Sâfì, M., Mustafa Sâfínin Zübdetü't-tevârîh'i, ed. İ.H. Çuhadar, 2 vols., Ankara 2003.

Watkins, T., Travels through Swisserland, Italy, Sicily, the Greek islands to Constantinople; through part of Greece, Ragusa, and the Dalmatian isles, 2 vols., London 1792.

\section{Secondary Sources}

Ágoston, G., Military transformation in the Ottoman Empire and Russia, 1500-1800, in Kritika: Explorations in Russian and Eurasian history 12 (2011), 281-319.

Akbulut, M.Y., The scramble for Iran: Ottoman military and diplomatic engagements during the Afghan occupation of Iran, 1722-1729, MA thesis, Boğaziçi University 2017. Aksan, V.H., An Ottoman statesman in war and peace: Ahmed Resmi Efendi, 1700-1783 (oEH 3), Leiden and New York 1995.

Aksan, V.H., Ottoman wars, 1700-1870: An empire besieged, Harlow 2007.

Alpay, İ.B., I. Sultan Abdülhamid Külliyesi ve Hamidiye Medresesi, in Sanat tarihi yıllı̆̆ı 8 (1978), 1-22.

Arnold, T.W., The caliphate, Oxford 1924.

Artan, T., Architecture as a theatre of life: Profile of the eighteenth century Bosphorus, PhD diss., Massachusetts Institute of Technology 1989.

Artan, T., Istanbul in the 18th century: Days of reconciliation and consolidation, in From Byzantion to Istanbul: 8000 years of a capital, Istanbul 2010, 300-312.

Ateş, İ., İstanbul Yeni Camive hünkar kasrı, Istanbul, n.d. [1977?].

Avcıoğlu, N., Ahmed I and the allegories of tyranny in the frontispiece to George Sandys's Relation of a journey, in Muqarnas 18 (2002), 203-226. 
Baer, M.D., Honored by the glory of Islam: Conversion and conquest in Ottoman Europe, Oxford and New York 2008.

Baraz, M.R.H., Teşrifat meraklısı beyzâde takımının oturduğu bir kibar semt Beylerbeyi, 2 vols., Istanbul 1994.

Barkan, Ö., Süleymaniye Cami ve Imareti inşaatı (1550-1557), 2 vols., Ankara 1972-1979.

Başaran, B., Selim III, social control and policing in Istanbul at the end of the eighteenth century: Between crisis and order (OE 56), Leiden 2014.

Bates, Ü.Ü., The patronage of Süleyman: The Süleymaniye Complex in Istanbul, Edebiyat fakültesi araştırma dergisi 9, in memoriam Prof. Albert Louis Gabriel (1978), $65^{-76 .}$

Batur, Afife, Selimiye Kışlası, in Dünden bugüne İstanbul ansiklopedisi, vi, $515-516$.

Batur, S., Beylerbeyi Camii, in Dünden bugüne İstanbul ansiklopedisi, ii, 203-205.

Batur, S., Selimiye Camii, in Dünden bugüne İstanbul ansiklopedisi, vi, 512-515.

Berridge, G.R., Diplomatic integration with Europe before Selim III, in A.N. Yurdusev (ed.), Ottoman diplomacy: Conventional or unconventional?, Basingstoke and New York 2004, 114-130.

Bilge, M., Üsküdar Ayazma Camii ve bölgede imarlaşma, in C. Yılmaz (ed.), Uluslararası Üsküdar sempozyumu VI, 6-9 Kasım 2008: Bildiriler, Istanbul 2009, 6o9-620.

Berberoğlu, B.N., Boğazın incileri: Yalı camileri = The pearls of Istanbul: Waterfront mosques, Istanbul 2010.

Boyar, E. and K. Fleet, A social history of Ottoman Istanbul, Cambridge and New York 2010.

Budak, S., "The temple of the incredulous": Ottoman sultanic mosques and the principle of legality, in Muqarnas 36 (2019), 179-207.

Burak, G., The second formation of Islamic law: The Hanafi school in the early modern Ottoman empire, Cambridge 2015.

Bülbül, A.H., IV. Vakıf Han'ın yerindeki önemli eser: Hamidiye imareti, in Vakıf restorasyon yıllı̆̆ı 4 (2012), 6-16.

Çelik, Z., The remaking of Istanbul: Portrait of an Ottoman city in the nineteenth century, Seattle and London 1986.

Cezar, M., Osmanlı devrinde İstanbul yapılarında tahribat yapan yangınlar ve tabii afetler, in Türk sanat tarihi araştırma ve incelemeleri 1 (1963), 327-414.

Crane, H., The Ottoman sultan's mosques: Icons of imperial legitimacy, in I.A. Bierman, R.A. Abou-El-Haj and D. Preziosi (eds.), The Ottoman city and its parts: Urban structure and social order, New Rochelle 1991, 173-243.

Cunbur, M., I. Abdülhamid vakfiyesi ve Hamidiye Kütüphanesi, in Dil ve tarih-coğrafya fakültesi dergisi 22 (1964), 17-69.

Dankoff, R. and S. Tezcan, An Evliya Çelebi bibliography, 2010, ${ }^{4} 2015$, https://lucian .uchicago.edu/blogs/ottomanturkish/files/2015/og/Evliya-Celebi-Bibliography.Sep tember-2015.pdf. Accessed: 6 December 2018. 
Depincé, M.Ch., Compte rendu des travaux du Congrès colonial de Marseille, 4 vols., Paris 1907-1908.

Deringil, S., The well-protected domains: Ideology and the legitimation of power in the Ottoman Empire 1876-19o9, London and New York 1998.

Duindam, J., Vienna and Versailles: The courts of Europe's dynastic rivals, 1550-1780, Cambridge and New York 2003.

Eldem, E., 18. yüzyll ve değişim, in Cogito 19 (1999), 189-199.

Emecen, F.M., Hilâfetin devri meselesi: Şaban-ı Şifâî ve Şehrizâde Mehmed Said'in görüşleri üzerine yorumlar, in F.M. Emecen et al. (eds.), Osmanlının izinde: Prof. Dr. Mehmet Ípşirli armağanı, Istanbul 2013, 561-574.

Eyice, S., Hamidiye Külliyesi, in TDVIA, xv, 465-468.

Fetvacı, E., Music, light and flowers: The changing aesthetics of Ottoman architecture, in Journal of Turkish studies 32 (2008), 221-240.

Finkel, C., Osman's dream: The story of the Ottoman Empire, 1300-1923, London 2005.

Goodwin, G., A history of Ottoman architecture, London 1971.

Hamadeh, S., The city's pleasures: Istanbul in the eighteenth century, Seattle and London 2008.

Hamadeh, S, Ottoman expressions of early modernity and the "inevitable" question of westernization, in Journal of the society of architectural historians 63 (2004), 3251.

Hamadeh, S., Public spaces and the garden culture of Istanbul in the eighteenth century, in V.H. Aksan and D. Goffman (eds.), The early modern Ottomans: Remapping the empire, Cambridge and New York 2007, 277-312.

Hamadeh, S., Westernization, decadence, and the Turkish Baroque: Modern constructions of the eighteenth century, in Muqarnas 24 (2007), 185-197.

Hammer-Purgstall, J. von, Geschichte des osmanischen Reiches, 10 vols., Pest 1827-1835. Haskan, M.N., Yüzyıllar boyunca Üsküdar, 3 vols., Istanbul 2001.

Heyd, U., The Ottoman 'ulemā and westernization in the time of Selīm III and Mahmūd II, in A. Hourani, P.S. Khoury and M.C. Wilson (eds.), The modern Middle East: A reader, Berkeley and Los Angeles 1993, 29-6o.

Hochhut, P., Die Moschee Nûruosmâniye in Istanbul: Beiträge zur Baugeschichte nach osmanischen Quellen, Berlin 1986.

İpşirli, M., Osmanlılarda Cuma selâmlığı (halk-hükümdar münâsebetleri açısından önemi), in Prof. Dr. Bekir Kütükoğlu'na armağan, Istanbul 1991, 459-471.

İşli, N., Karacaahmet Mezarlığı, in TDVIA, xxiv, 375-377.

Karateke, H.T., Opium for the subjects? Religiosity as a legitimizing factor the Ottoman sultan, in H.T. Karateke and M. Reinkowski (eds.), Legitimizing the order: The Ottoman rhetoric of state power ( $\mathrm{OE} \mathrm{H} 34$ ), Leiden and Boston 2OO5, 111-129.

Karpat, K.H., The politicization of Islam: Reconstructing identity, state, faith, and community in the late Ottoman State, Oxford and New York 2001. 
Keskiner, B., Ü. Rüstem and T. Stanley, Armed and splendorous: The jeweled gun of Sultan Mahmud I, in A. Landau (ed.), Pearls on a string:Artists, patrons, and poets at the great Islamic courts, Baltimore 2015, 205-241.

Kuban, D., Notes on building technology of the 18th century. The building of the Mosque of Nuruosmaniye at Istanbul, according to "Tarih-î camii şerif-î Nur-u Osmanî," in I. Uluslararası Türk-İslâm bilim ve teknoloji tarihi kongresi, 14-18 Eylül 1981: Bildiriler [I. International congress on the history of Turkish-Islamic science and technology, 14-18 September 1981: Proceedings], 5 vols., Istanbul 1981, v, 271-293.

Kuban, D., Ottoman architecture, trans. A. Mill, Woodbridge 2010.

Kuban, D., Tarih-i cami-i şerif-i Nur-u Osmanî ve onsekizinci yüzyıl Osmanlı yapı tekniği üzerine gözlemler, in Türk ve İslâm sanatı üzerine denemeler, Istanbul 1982, 123-140.

Kuban, D., Türk Barok mimarisi hakkında bir deneme, Istanbul 1954.

Kuran, A., The evolution of the sultan's pavilion in Ottoman imperial mosques, in Islamic art 4 (1990-1991), 281-301.

Kurz, M., Ways to heaven, gates to hell: Fażlīzāde 'Alìs struggle with the diversity of Ottoman Islam (BoIS 25), Berlin 2011.

Ledoux-Prouzeau, M., Les fêtes publiques à Paris à l' époque de la guerre de Succession d'Autriche (1744-1749), in D. Rabreau (ed.), Paris, capitale des arts sous Louis XV:Peinture, sculpture, architecture, fêtes, iconographie, Bordeaux 1997, 87-110.

Lewis, B., What went wrong? Western impact and Middle Eastern response, Oxford and New York 2002.

Melo, J.V., Respect and superiority: The ceremonial rules of Goan diplomacy and the survival of the Estado da Índia, 1707-175o, in Portuguese studies 28 (2012), 143-158.

Naff, T., Ottoman diplomatic relations with Europe in the eighteenth century: Patterns and trends, in T. Naff and R. Owen (eds.), Studies in eighteenth century Islamic history, Carbondale and Edwardsville; London and Amsterdam 1977, 88-107.

Naquin, S. and E.S. Rawski, Chinese society in the eighteenth century, New Haven and London 1987.

Nayır, Z., Osmanlı mimarlığında Sultan Ahmet Külliyesi ve sonrası (1609-169o), Istanbul 1975.

Necipoğlu, G., The age of Sinan: Architectural culture in the Ottoman Empire, London $2007,{ }^{2} 2011$ (with corrections).

Necipoğlu, G., Architecture, ceremonial, and power: The Topkapı Palace in the fifteenth and sixteenth centuries, New York and Cambridge 1991.

Necipoğlu, G., Challenging the past: Sinan and the competitive discourse of early modern Islamic architecture, in Muqarnas 10 (1993), 169-180.

Neftçi, A. Lâleli Külliyesi'nin inşaat süreci, PhD diss., Istanbul Teknik Üniversitesi 2002.

Neftçi, A., Nuruosmaniye Camii açlış töreni (with an English summary: The inauguration of the Nuruosmaniye Mosque), in Sanat tarihi defterleri 11 (2007), 1-28. 
Olson, R., The siege of Mosul and Ottoman-Persian relations, 1718-1743, Bloomington 1975. Özervarl, M.S., Between tension and rapprochement: Sunni-Shi'ite relations in the pre-modern Ottoman period, with a focus on the eighteenth century, in Historical research 90 (August 2017), 526-542.

Özcan, A., Mustafa II, in TDVIA, xxxi, $275^{-28}$ o.

Özgüleş, M., The women who built the Ottoman world: Female patronage and the architectural legacy of Gülnuş Sultan, London and New York 2017.

Peker, A.U., Return of the sultan: Nuruosmânîye Mosque and the Istanbul Bedestan, in C. Bilsel et al. (eds.), Constructing cultural identity, representing social power, Pisa 2010, 139-157.

Rüstem, Ü., Ottoman Baroque: The architectural refashioning of eighteenth-century Istanbul, Princeton and Oxford 2019.

Rüstem, Ü., The spectacle of legitimacy: The dome-closing ceremony of the Sultan Ahmed Mosque, in Muqarnas 33 (2016), 253-344.

Rüstem, Ü., Victory in the making: The symbolism of Istanbul's Nusretiye Mosque, in A. Ohta et al. (eds.), Art, trade, and culture in the Islamic world and beyond: From the Fatimids to the Mughals. Studies presented to Doris Behrens-Abouseif, London 2016, 92-115.

Sarıcaoğlu, F., Kendi kaleminden bir padişahın portresi: Sultan I. Abdülhamid (1774-1789), Istanbul 2000.

Sav, M. (ed)., Nuruosmaniye Camii:Külliyenin algısıve 2010-2014 restorasyon çalışmaları, Istanbul 2016.

Shaw, S.J., Between old and new: The Ottoman Empire under Sultan Selim III, 1789-1807, Cambridge, MA, 1971.

Shaw, S.J., History of the Ottoman Empire and modern Turkey, i, Empire of the gazis: The rise and decline of the Ottoman Empire, 1280-1808, Cambridge and New York 1976.

Suman, S., Questioning an "icon of change": The Nuruosmaniye complex and the writing of Ottoman architectural history, in METU journal of the faculty of architecture 28 (2011), 145-166.

Tanman, M.B., Kasr-ı hümâyun, in TDVIA, xxiv, 573-575.

Tanman, M.B., Selimiye Tekkesi, in Dünden bugüne İstanbul ansiklopedisi, vi, Istanbul 1994, 516-518.

Tanyeli, G., Laleli Külliyesi, in Dünden bugüne İstanbul ansiklopedisi, v, Istanbul 1994, 190-193.

Terzioğlu, D., How to conceptualize Ottoman Sunnitization, in Turcica 44 (2012-2013), 301-338.

Terzioğlu, D., The imperial circumcision festival of 1582: An interpretation, in Muqarnas 12 (1995), 84-100.

Thys-Şenocak, L., Ottoman women builders: The architectural patronage of Hadice Turhan Sultan, Aldershot and Burlington 2006. 
Thys-Şenocak, L., The Yeni Valide Mosque complex at Eminönü, in Muqarnas 15 (1998), $5^{8-70 .}$

Thys-Şenocak, L., The Yeni Valide Mosque complex of Eminönü, Istanbul (1597-1665): Gender and vision in Ottoman architecture, in D.F. Ruggles (ed.), Women, patronage, and self-representation in Islamic societies, Albany 200o, 69-89.

Tierney, E., with C. Schnitzer, Urban festival, in M. Snodin and N. Llewellyn (eds.), Baroque, 1620-1800: Style in the age of magnificence, London 2009, 166-188.

Tucker, E., Nadir Shah and the Ja'fari madhhab reconsidered, in Iranian Studies 27 (1994), 163-179.

Tucker, E., The peace negotiations of 1736: A conceptual turning point in OttomanIranian Relations, in Turkish studies association bulletin 20 (1996), 16-37.

Tuğ, B. Politics of honor in Ottoman Anatolia: Sexual violence and socio-legal surveillance in the eighteenth century (OEH 62), Leiden and Boston 2017.

Weismann, I., The Naqshbandiyya: Orthodoxy and activism in a worldwide Sufi tradition, London and New York 2007.

Wharton[-Durgaryan], A., The architects of Ottoman Constantinople: The Balyan family and the history of Ottoman architecture, London and New York 2015.

Yaycioglu, A., Janissaires, ingénieurs et prédicateurs. Comment l'ingénierie militaire et l' activisme islamique changèrent l' ordre ottoman, in Revue d'histoire du XIXe siècle 53 (2016), 19-37.

Yaycioglu, A., Partners of the Empire: The crisis of the Ottoman order in the age of revolutions, Palo Alto 2016.

Yllmaz, H., Caliphate redefined: The mystical turn in Ottoman political thought, Princeton 2018.

Yllmaz, H.K., Aziz Mahmûd Hüdâyî, in TDVIA, iv, 338-340.

Yücel, E. Yeni Cami hünkâr kasrı, Istanbul 1972.

Zarinebaf, F., Crime and punishment in Istanbul: 1700-1800, Berkeley 2010.

Zarinebaf[-Shahr], F., Qızılbash "heresy" and rebellion in Ottoman Anatolia during the sixteenth century, in Anatolia Moderna [Yeni Anadolu] 7 (1997), 1-15.

Zilfi, M.C., A medrese for the palace: Ottoman dynastic legitimation in the eighteenth century, in JAOS 113 (1993), 184-191.

Zilfi, M.C., The Politics of piety: The Ottoman ulema in the postclassical age (1600-1800), Minneapolis 1988.

Zilfi, M.C., Women and slavery in the late Ottoman Empire: The design of difference, New York 2010. 